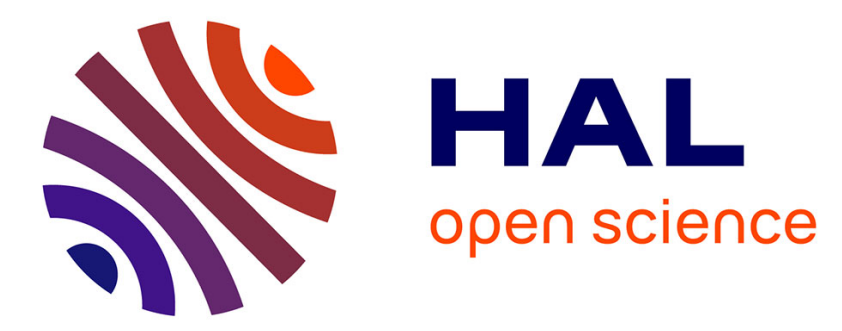

\title{
Orbital chronology of the Pliensbachian - Toarcian transition from the Central High Atlas Basin (Morocco)
}

Stephane Bodin, Mathieu Martinez, Francois-Nicolas Krencker, Emanuela Mattioli

\section{- To cite this version:}

Stephane Bodin, Mathieu Martinez, Francois-Nicolas Krencker, Emanuela Mattioli. Orbital chronology of the Pliensbachian - Toarcian transition from the Central High Atlas Basin (Morocco). Newsletters on Stratigraphy, 2017, 50 (1), pp.47-69. 10.1127/nos/2016/0311 . hal-02358952

\section{HAL Id: hal-02358952 \\ https://univ-lyon1.hal.science/hal-02358952}

Submitted on 20 Sep 2021

HAL is a multi-disciplinary open access archive for the deposit and dissemination of scientific research documents, whether they are published or not. The documents may come from teaching and research institutions in France or abroad, or from public or private research centers.
L'archive ouverte pluridisciplinaire HAL, est destinée au dépôt et à la diffusion de documents scientifiques de niveau recherche, publiés ou non, émanant des établissements d'enseignement et de recherche français ou étrangers, des laboratoires publics ou privés.

\section{(ㄷ)(1) $\$$}

Distributed under a Creative Commons Attribution - NonCommerciall 4.0 International 


\title{
Orbital chronology of the Pliensbachian-Toarcian transition from the Central High Atlas Basin (Morocco)
}

\author{
Mathieu Martinez ${ }^{1 *}$, François-Nicolas Krencker ${ }^{2,3}$, Emanuela Mattioli ${ }^{4}$, \\ and Stéphane Bodin ${ }^{2,5}$
}

With 9 figures and 1 table

\begin{abstract}
The Pliensbachian-Toarcian transition has been studied in depth for the major environmental changes and the marine invertebrate biodiversity crisis observed at that time. Despite a large number of studies performed, the time frames provided for this interval show large discrepancies from author to author. Major environmental changes occurring at that time impacted the sedimentation pattern and sedimentation rates, making uncertain the construction of time scales. Here, we provide a new astrochronological framework based on an expanded hemipelagic section from the Central High Atlas Basin (Morocco). $\delta^{13} \mathrm{C}$ and $\mathrm{CaCO}_{3}$ measurements performed on the studied section allowed the construction of an orbital time scale based on the 405-kyr eccentricity and the obliquity cycles. This orbital time scale is then compared to the Peniche section (GSSP of the Toarcian Stage) in order to limit the effects of eventual condensation and erosion events on the construction of the orbital time scale. The duration of the early Toarcian Polymorphum Zone is then assessed at 0.9-1.0 myr, while the interval from the base of the Toarcian Stage to the FO of C.superbus is assessed at 0.51 myr. This long duration of the Polymorphum Zone highlights the fact that numerous sections in Europe are affected by long-term condensation and hiati around the Pliensbachian-Toarcian transition. Finally, we also explore the potential of the Central High Atlas basin to provide a refined time scale for the late Pliensbachian. Preliminary data lead to a duration assessment of the NJ5b calcareous nannofossil zone of at least $2.07 \mathrm{myr}$, and to a mean duration of the Emaciatum ammonite zone of 2.05 myr. These durations are $\sim 1 \mathrm{myr}$ longer than the durations proposed in the Geological Time Scale 2012, which illustrates the potential of the Central High Atlas Basin for calibrating the Pliensbachian times.
\end{abstract}

Key words. Toarcian, Pliensbachian, cyclostratigraphy, P-To event, High Atlas, carbon-isotopes

\footnotetext{
Authors' addresses:

1 MARUM: Center for Marine Environmental Sciences, Universität Bremen, Leobenerstr., 28359 Bremen, Germany.

2 Ruhr-Universität Bochum, Institut für Geologie, Mineralogie und Geophysik, 44870 Bochum, Germany.

3 Present address: Halliburton (Neftex), 97 Jubilee Avenue, Milton Park, Abingdon, Oxfordshire OX14 4RW, United Kingdom.

4 Univ Lyon, Université Claude Bernard Lyon 1, Ens de Lyon, CNRS, UMR 5276 LGL-TPE, F-69622, Villeurbanne, France.

5 Present address: Department of Geoscience, Aarhus University, DK-8000 Aarhus C, Denmark.

* Corresponding author: mmartinez@marum.de
} 


\section{Introduction}

The construction of a robust Geological Time Scale is of critical importance for assessing the rhythms of geodynamic changes, palaeoceanographic and palaeoclimatic processes. The last update of the Geological Time Scale 2012 (GTS 2012, Gradstein et al. 2012) has shown to contain some non-negligible uncertainties, which can reach several millions of years (Pellenard et al. 2013, De Vleeschouwer and Parnell 2014, Vennari et al. 2014, Martinez et al. 2015). Yet, the development of extended astrochronological frameworks has already contributed to the construction of a robust geological time frame for the Cenozoic (e.g. Lourens et al 2004). The construction of new astrochronological frameworks are currently extended for Jurassic and Cretaceous successions in order to decrease the time uncertainty of those periods by at least one order of magnitude (Weedon and Jenkyns 1999, Huang et al. 2010, Martinez et al. 2015).

One of the critical intervals of the Jurassic Period is the Pliensbachian-Toarcian transition. This time interval is affected by two global palaeoenvironmental changes, respectively at the Pliensbachian-Toarcian transition (the Pliensbachian-Toarcian event or P-To event) and the Toarcian oceanic anoxic event (T-OAE) at the base of the Levisoni/Serpentinum Zone. These events are characterised by excursions in the $\delta^{13} \mathrm{C}$ records (Hesselbo et al. 2007, Suan et al. 2008a, Bodin et al. 2010, 2016), increased accumulation of organic matter observed during the T-OAE (e.g. Jenkyns 1988), higher levels of continental weathering and nutrient supply (Cohen et al. 2004, Dera et al. 2009, Bodin et al. 2010, 2011), demise of the carbonate platform factories (Bassoullet and Baudin 1994, Suan et al. 2008a, Wilmsen and Neuweiler 2008, Léonide et al. 2012, Krencker et al. 2014), and extinction events affecting marine invertebrates (Little and Benton 1995, Caruthers et al. 2013). These environmental changes were further accompanied by major changes in palaeotemperature (Jenkyns 2003, Suan et al. 2008a, 2010, Dera et al. 2011a) and sea level (Hesselbo 2008, Sabatino et al. 2009, Suan et al. 2010 and references therein, Pittet et al. 2014), likely linked to the growth and decay of polar ice caps (Suan et al. 2010, Korte and Hesselbo 2011). All these environmental changes triggered major turnovers in facies, environment and/ or sedimentation rate (Bassoullet and Baudin 1994, de Graciansky et al. 1998, Hesselbo and Jenkyns 1998, Léonide et al. 2012, Pittet et al. 2014, Ruebsam et al. 2014). Major sea-level changes are notably responsi- ble for the recurrence of condensed intervals and hiatal surfaces recorded in the early Toarcian (Léonide et al. 2012, Pittet et al. 2014). As a consequence, attempts to build a robust time scale in this time interval led to diverging astrochronological interpretations (Suan et al. 2008b, Kemp et al. 2011, Huang and Hesselbo 2014, Ruebsam et al. 2014). The first ammonite zone of the Toarcian (i.e. the Tenuicostatum or Polymorphum Zone) is particularly representative of this debate, duration estimates based on orbital time scales fluctuating over almost two orders of magnitude, from 0.09 myr to $\sim 1.15$ myr (Mattioli and Pittet 2004, Suan et al. 2008b, Boulila et al. 2014, Ruebsam et al. 2014). The construction of high-resolution astrochronological frameworks ideally requires a continuous and expanded sedimentary record with a minimum of condensation, suggesting that the previously studied sections were not suited for improving of the Pliensbachian-Toarcian time scale.

The Central High Atlas Basin of Morocco has experienced high tectonic subsidence in the Triassic, renewed at a moderate rate during the Early Jurassic (Frizon de Lamotte et al. 2008). As a result, during the Pliensbachian-Toarcian, expanded sections were deposited in hemipelagic environments (Bodin et al. 2011, 2016). These sections are much expanded compared to the European sections reported at the Pliensbachian-Toarcian transition, which is expected to limit the occurrence of condensation or hiati.

In the Foum Tillicht section, spectral analyses have been performed on high-resolution $\delta^{13} \mathrm{C}$ and $\mathrm{CaCO}_{3}$ records covering the Pliensbachian-Toarcian transition. In addition, $\delta^{13} \mathrm{C}$ and $\mathrm{CaCO}_{3}$ were measured in the Pliensbachian part of the series, although at a lower resolution, which provides the opportunity to evaluate the potential of the Foum Tillicht section to record the long eccentricity cycle ( $405 \mathrm{kyr})$. Further, we test if it can be used as a reference section for further calibrations of the late Pliensbachian time scale.

\section{Geological setting}

\subsection{The Central High Atlas Basin}

The Central High Atlas Basin is part of an Atlantic aulacogen rift system (Frizon de Lamotte et al. 2008). This is a rift basin opened in the Triassic during the dislocation of Gondwana as the result of transtensive movements. A renewed phase of tectonic subsidence started in the late Pliensbachian (Frizon de Lamotte et 


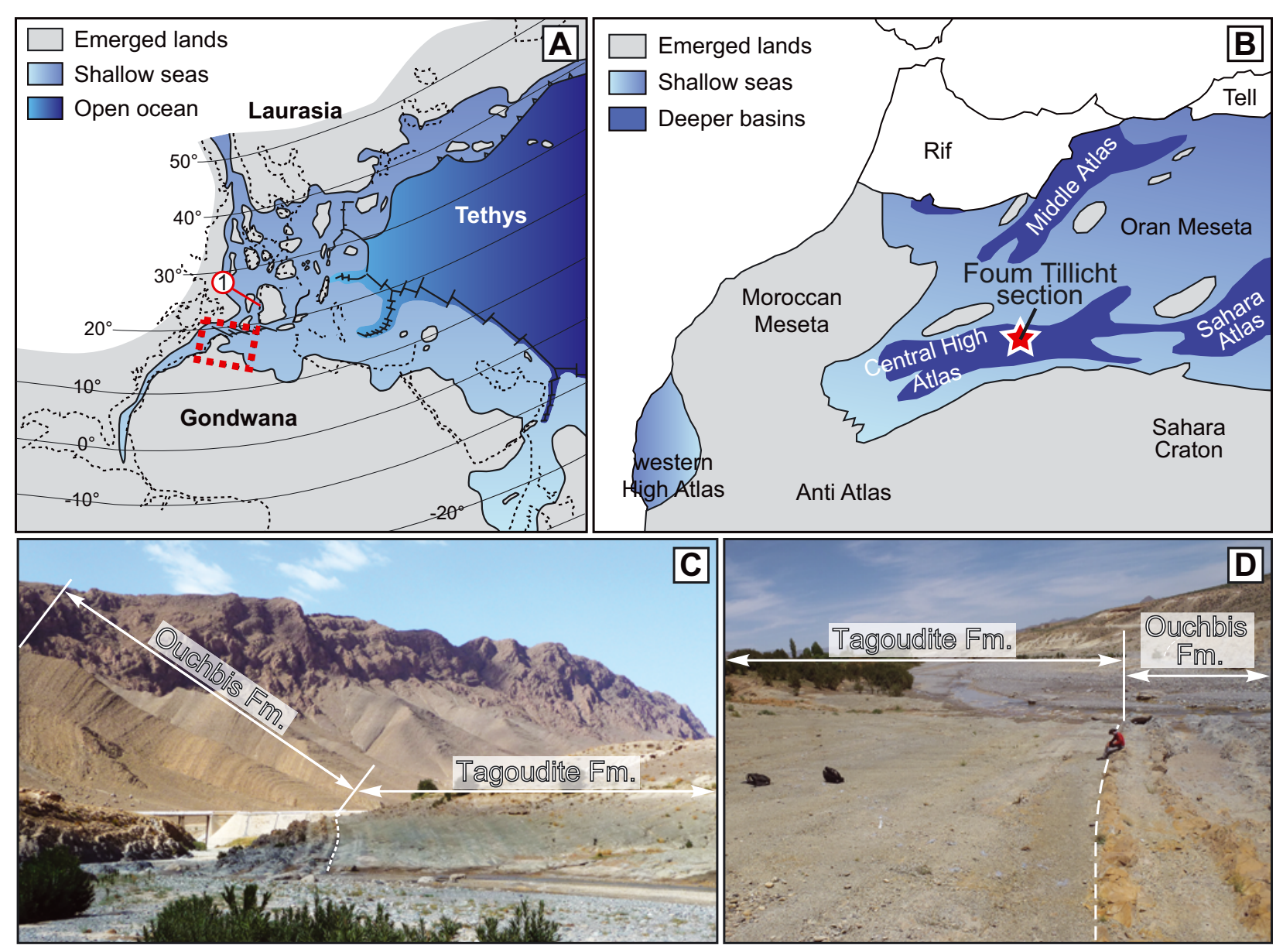

Fig. 1. Geological setting of the Foum Tillicht section. A. Palaeogeographic map of the western Tethys during the Early Jurassic. The dashed rectangle shows the limit of the second map. Mark "1" indicates the location of the Peniche section. B. Geographic map of Morocco and western Algeria showing the main geological provinces and the location of the Foum Tillicht section within the Central High Atlas basin (maps from Bodin et al. 2010). C. Overview of the Foum Tillicht section, showing the Ouchbis and Tagoudite formations. Contrasts have been enhanced to show colour variations in the Tagoudite formation D. Detailed view of the Pliensbachian-Toarcian transition in the Foum Tillicht section.

al. 2008). The subsequent creation of accommodation space allowed for the deposition of an expanded and continuous sedimentary record spanning the Pliensbachian-Toarcian interval (Piqué et al. 2002).

During the Early Jurassic, the Central High Atlas Basin was located at the northern margin of Gondwana, at a palaeolatitude of $\sim 15^{\circ} \mathrm{N}$. It was separated from the nascent Atlantic Ocean by the Moroccan Meseta (also called West Moroccan Arch), and open at its eastern side to the Tethys Ocean (Fig. 1, Bassoulet et al. 1993). The southern, western and northwestern borders of the Central High Atlas Basin were the loci of extensive shallow-water carbonate production during the Hettangian-Pliensbachian (du Dresnay 1971, Milhi et al. 2002, Wilmsen and Neuweiler 2008). This was followed by a rapid demise in neritic carbonate production, occurring at the Pliensbachian-Toarcian transition and related to a climatic change, from arid towards more humid conditions during the earliest Toarcian (Wilmsen and Neuweiler 2008, Bodin et al. 2010, 2016, Krencker et al. 2015). As a consequence, a major lithological break marks the PliensbachianToarcian transition in Morocco: in both shallow- and deep-water settings, carbonate-rich Pliensbachian sedimentary rocks are overlain by siliciclastic-rich Toarcian sediments.

\subsection{Lithology and biostratigraphy of the Foum Tillicht section}

The here-studied Foum Tillicht section is situated within the central part of the Central High Atlas Basin, 
approximately $10 \mathrm{~km}$ northwest of the city of Rich (Fig. 1), on the eastern side of the N13 main road. It encompasses the upper part of the Ouchbis Formation and the lower part of the Tagoudite Formation, and covers the Pliensbachian-Toarcian transition (Fig. 1; Wilmsen and Neuweiler 2008). The Ouchbis Formation is composed of fine-grained marl-limestone alternations showing rhythmic changes of the limestone to marl ratio, deposited in a hemipelagic environment (Fig. 1). Ammonites, belemnites and calcareous nannofossils have been encountered. The Ouchbis Formation is followed by the Tagoudite Formation (Fig. 1), a fine-grained clayey carbonate sequence showing, in its medium and upper part, numerous intercalations of fine-to-medium grained siliciclastic beds, interpreted as turbidite deposits (Bodin et al. 2016).

The integration of biostratigraphic data from European basins led to the definition of three standard ammonite zonations (Subboreal, Tethyan and Mediteranean) and two standard calcareous nannofossil zonations for northwestern Europe and western Mediterranean countries (Cariou and Hantzpergue 1997, Bown and Cooper 1998, Mattioli and Erba 1999, Page 2003, Bilotta et al. 2010, Gradstein et al. 2012, Mattioli et al. 2013, Fraguas et al. 2015). The ammonite zonation of the Foum Tillicht section is based on the Mediterranean zonation, while the calcareous nanno- fossil zonation is based on the Tethyan zonation (Bodin et al. 2016). Figures 2 and 3 detail the chronostratigraphic relationships between the different zonations covering the Pliensbachian-Toarcian transition.

Scarcity of ammonite in the Ouchbis Formation did not allow the ammonite zones in the late Pliensbachian to be precisely bounded. The FO of nannofossil $\mathrm{Lo}$ tharingius sigillatus, defining the base of the NJ5b nannofossil zone, is recorded at $52.4 \mathrm{~m}$ (Bodin et al. 2016). Nonetheless, the first sample analysed for nannofossil assemblages below 52.4-m level is located at $36 \mathrm{~m}$, implying that the uncertainty of the location of the FO of L.sigillatus is at least $16.4 \mathrm{~m}$. The Pliensbachian-Toarcian boundary is marked by the massive appearance of ammonite Dactylioceras sp., in the last three beds of the Ouchbis Formation. This is confirmed by the first occurrence (FO) of the coccolith Discorhabdus ignotus at $109 \mathrm{~m}$ (Bodin et al. 2010, 2016, Mattioli et al. 2013).

In the transition from the Ouchbis Formation to the Tagoudite Formation, Wilmsen et al. (2002) reported several specimen of Harpoceras sp. According to these authors, this dates the base of the Tagoudite Formation at Foum Tillicht from the lowermost, but not basal, Polymorphum/Tenuicostatum ammonite Zone, suggesting a biostratigraphic condensation at the transition between the two formations. However, no phys-

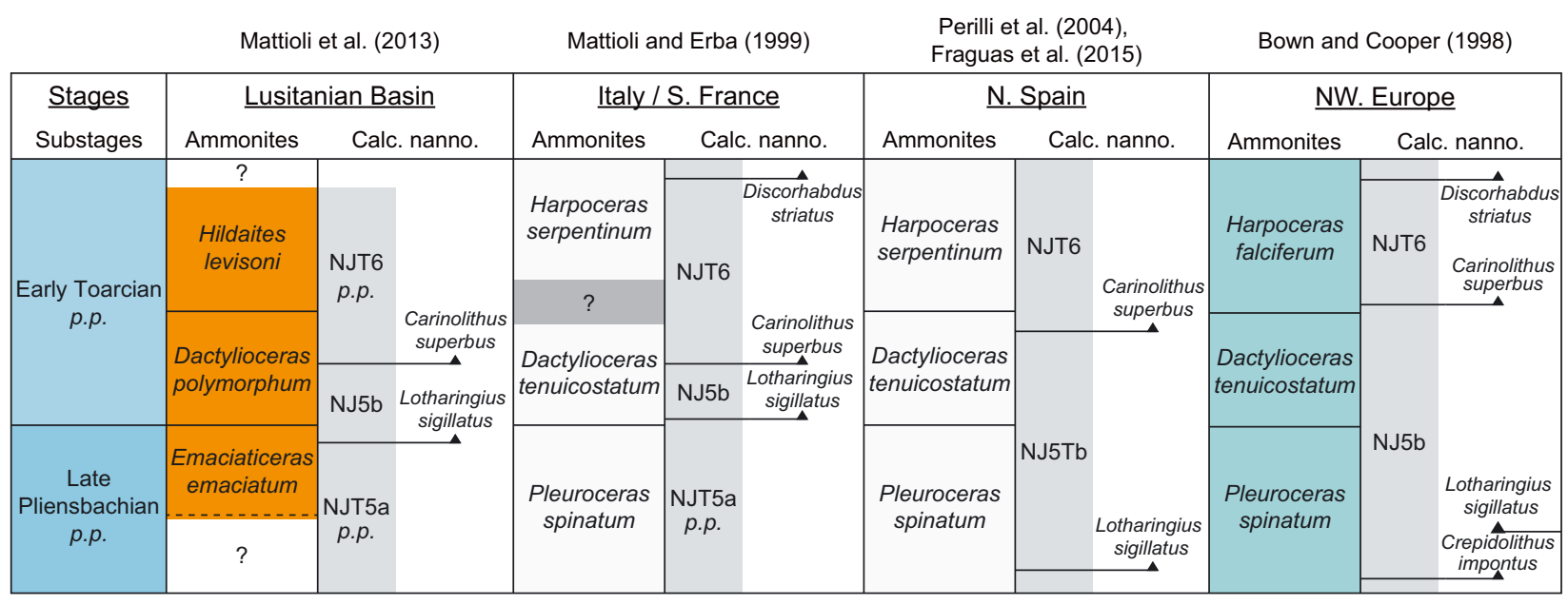

Fig. 2. Comparison of ammonite and calcareous nannofossil zones from Portugal (Lusitanian Basin), Italy and Southern France, Northern Spain, and Northwestern Europe modified from Perilli et al. (2004). The correlation scheme from Perilli et al. (2004) is modified as follows: Lusitanian Basin: correlations between ammonite zones and calcareous nannofossil zones are from Mattioli et al. (2013). Italy/S. France: correlations between ammonite zones and calcareous nannofossil zones are from Mattioli and Erba (1999). The question mark positioned between the D.tenuicostatum and the H. serpentinum zones takes into account the biostratigraphic data from Bilotta et al. (2010). N. Spain: correlations between ammonite zones and calacareous nannofossil zones are from Perilli et al. (2004) with updates from Fraguas et al. (2015). NW Europe: correlations are from Bown and Cooper (1998). 
Fig. 3. Standard zonation schemes at the Pliensbachian-Toarcian transition (from Cariou and Hantzpergue 1997, Gradstein et al. 2012). Correlations between the standard Tethyan and Subboreal ammonite zones with Tethyan and Boreal calcareous nannofossil zones reported in the GTS 2012 (Gradstein et al. 2012) are generated here using software Time Scale Creator 6.4.
Cariou and Hantzpergue (1997),

GTS 2012 (Gradstein et al. 2012)

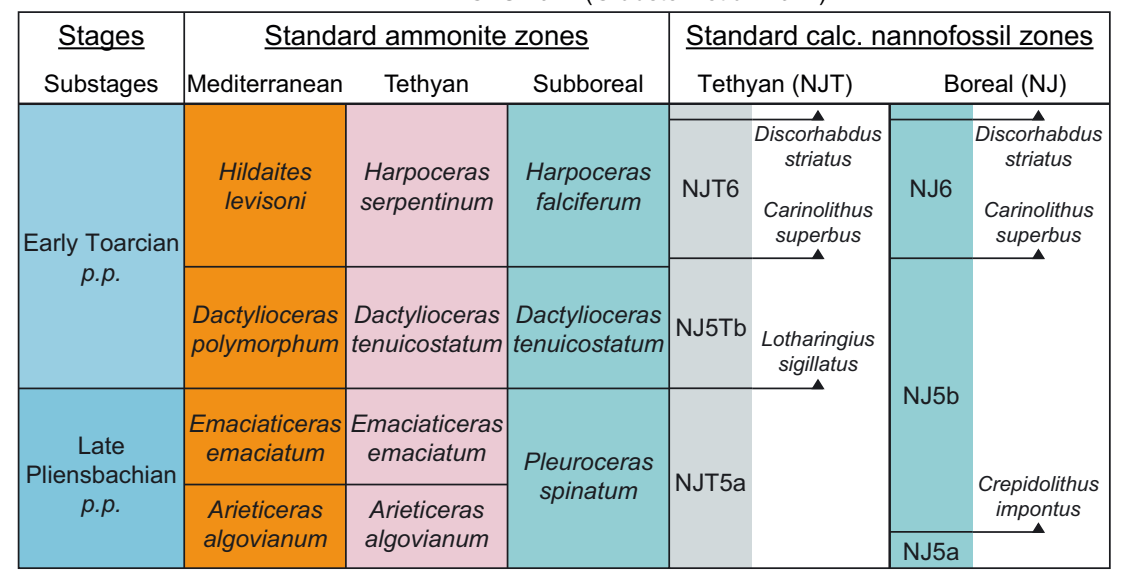

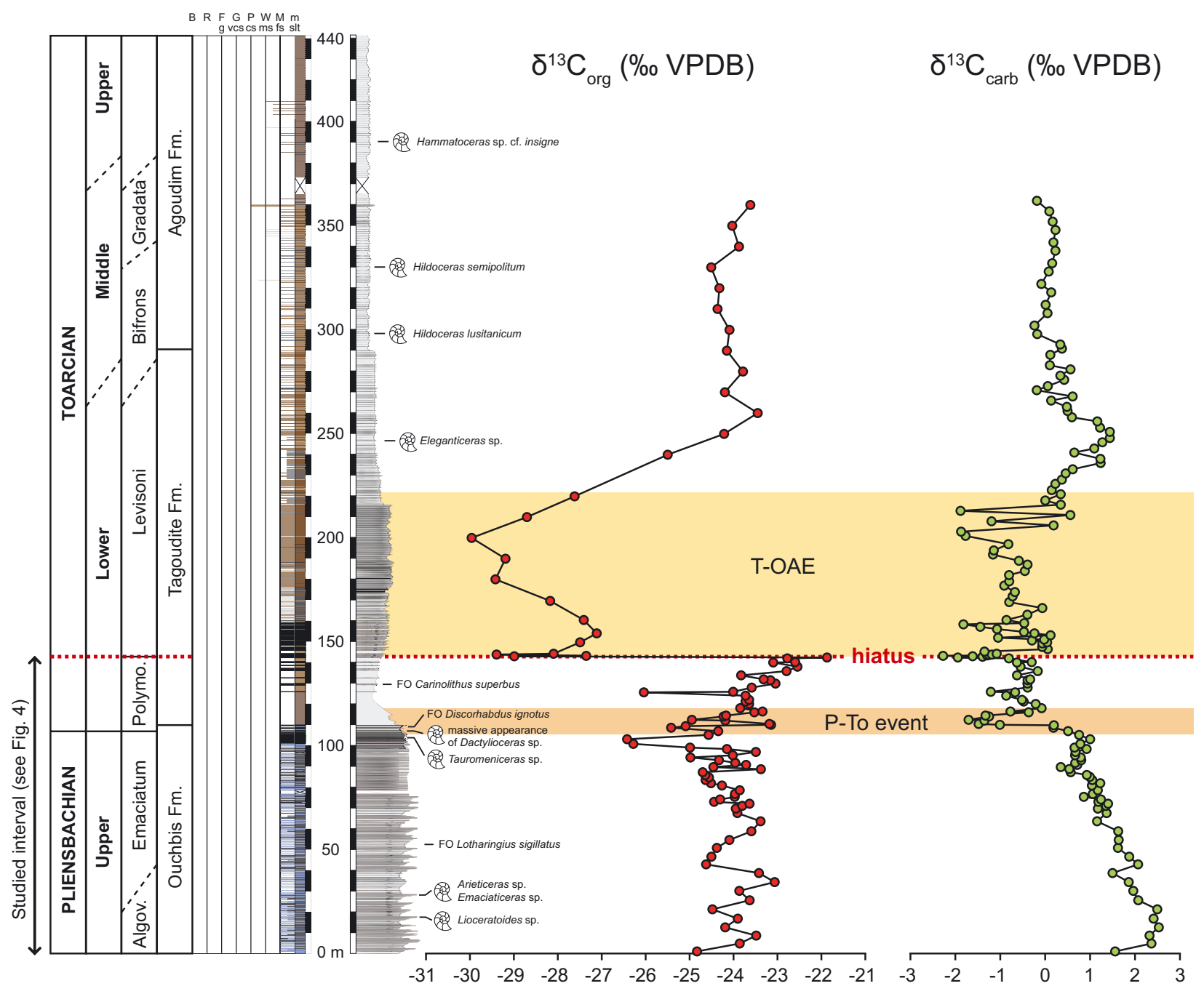

Fig. 4. Biostratigraphic, lithostratigraphic and carbon-isotope chemostratigraphic framework of the Foum Tillicht section (from Bodin et al. 2016). 
ical evidence for condensation, such as high-density bioturbation, glauconite or any other mineralization, was observed at this level. At $129.24 \mathrm{~m}$, the FO of Carinolithus superbus, defining the base of the NJT6 nannofossil zone, has been recorded (Bodin et al. 2016). This zone usually corresponds to the upper part of the Polymorphum/Tenuicostatum ammonite Zone (Mattioli and Erba 1999, Mattioli et al. 2013). In this interval, nannofossil assemblages were analysed every $1.5 \mathrm{~m}$, giving the minimum uncertainty on the position of the FO of C.superbus. At $142.25 \mathrm{~m}$, a hiatus has been interpreted based on carbon isotope chemostratigraphy (Bodin et al. 2016; Fig. 4). This coincides with the base of one prominent turbidite bed. Using organic matter carbon isotope chemostratigraphy, Bodin et al. (2016) were able to show that this hiatus corresponds to the upper part of the Polymorphum zone and the lower part of the Levisoni ammonite zone (Fig.4).

The boundary between the Ouchbis Formation and the Tagoudite Formation corresponds to the interval of the $\mathrm{P}$-To event, recorded by a reduction in the values and amplitudes of the $\delta^{13} \mathrm{C}$ and $\mathrm{CaCO}_{3}$ data (see section 4; Figs.4, 5). Bodin et al. (2016) defined the P-To event as the interval starting from the lithological change at $105.38 \mathrm{~m}$ and ending at the local maximum of $\delta^{13} \mathrm{C}_{\text {carb }}$ values at $117.91 \mathrm{~m}$.

\section{Material and Methods}

\subsection{Measurements of $\delta^{13} \mathrm{C}$ and $\mathrm{CaCO}_{3}$}

A total of 237 bulk micrite samples from the upper Pliensbachian to lower Toarcian interval were collected across the Foum Tillicht section at an average uneven step of $2.08 \mathrm{~m}$ from the base of the series to $67.55 \mathrm{~m}$, at an average uneven step of $1.05 \mathrm{~m}$ from 67.55 to $109.37 \mathrm{~m}$ and then with an even step of $0.20 \mathrm{~m}$ from $109.37 \mathrm{~m}$ to the top of the studied series. For each horizon, several milligrams of the micritic part of non-weathered limestone and marlstone samples lacking allochems and diagenetic veins were selected, ground to powder and homogenised in an agate mortar. Geochemical analyses performed on all samples include carbon $\left(\delta^{13} \mathrm{C}_{\text {carb }}\right)$ isotope composition and carbonate contents. These analyses complement the ones presented in Bodin et al. (2016).

\subsection{Carbonate content analyses}

The carbonate content of bulk rock samples were measured from $69.7 \mathrm{~m}$ to $142.15 \mathrm{~m}$. Carbonate con- tents were determined using the total inorganic carbon (TIC) contents of the samples at the Ruhr University of Bochum. The TIC values were determined using a Carbon Sulfur Determinator CS 500 (Eltra $\mathrm{GmbH}$ ). Depending on the lithology (marlstone or limestone), between 100 to $500 \mathrm{mg}$ of material were weighted in an Erlenmeyer flask, and reacted with $12.5 \mathrm{~mL}$ of diluted phosphoric acid $\left(\mathrm{H}_{3} \mathrm{PO}_{4} / \mathrm{H}_{2} \mathrm{O} 1: 1\right)$ injected in three doses. The amount of $\mathrm{CO}_{2}$ produced by this reaction was measured by infrared detector through an oxygen stream and used to determine the sample TIC contents. The quality of the measurements was controlled and corrected using calibration curves based on internal standards with known carbonate contents. Individual samples were measured with a precision better than $5 \%$. Replicate analyses of samples have a precision better than $6 \%$ on average.

\subsection{Inorganic carbon isotope analyses}

Carbon isotope analyses of bulk micrite carbonate $\left(\delta^{13} \mathrm{C}_{\text {carb }}\right)$ was performed in the whole studied interval using a Gasbench II coupled to a Finnigan MAT 253 mass spectrometer. Depending on the calcium carbonate content of individual samples, between 0.4 to $1.7 \mathrm{mg}$ of powder were weighed in vials and dried for $48 \mathrm{~h}$ in a $105^{\circ} \mathrm{C}$ preheated oven and subsequently cooled in a refrigerator for $1 \mathrm{~h}$. The air present in the vials was flushed using helium in order to avoid any contamination. Carbonates were sublimated by adding anhydrous phosphoric acid (104\%) using an autosampler. The isotopic composition is reported as $\delta$-value in parts per mil [\%o] relative to the international Vienna PDB (V-PDB) standard. The quality of the measurements was controlled by NBS19, NBS18 and RUB internal standards. Isotope data were corrected using $\mathrm{CO} 1$ and $\mathrm{CO} 8$ carbonate standards. For micrite samples the reproducibility $(3<\mathrm{n}<4)$ calculated with the Ruhr University of Bochum internal standard was better than $\pm 0.08 \%$ for $\delta^{13} C_{\text {carb }}$. Sample processing and stable isotope analyses were carried out at the Ruhr University of Bochum.

\subsection{Spectral analyses}

The long-term evolutions of the $\delta^{13} \mathrm{C}_{\text {carb }}$ and $\mathrm{CaCO}_{3}$ series are marked by a sudden decrease of the $\delta^{13} \mathrm{C}_{\text {carb }}$ and $\mathrm{wt} \% \mathrm{CaCO}_{3}$ values at the transition between the Ouchbis and Tagoudite formations (Fig. 5). Prior to spectral analyses, the long-term trends of the series were thus calculated and subtracted using piecewise linear regressions. Since the data are not collected at 


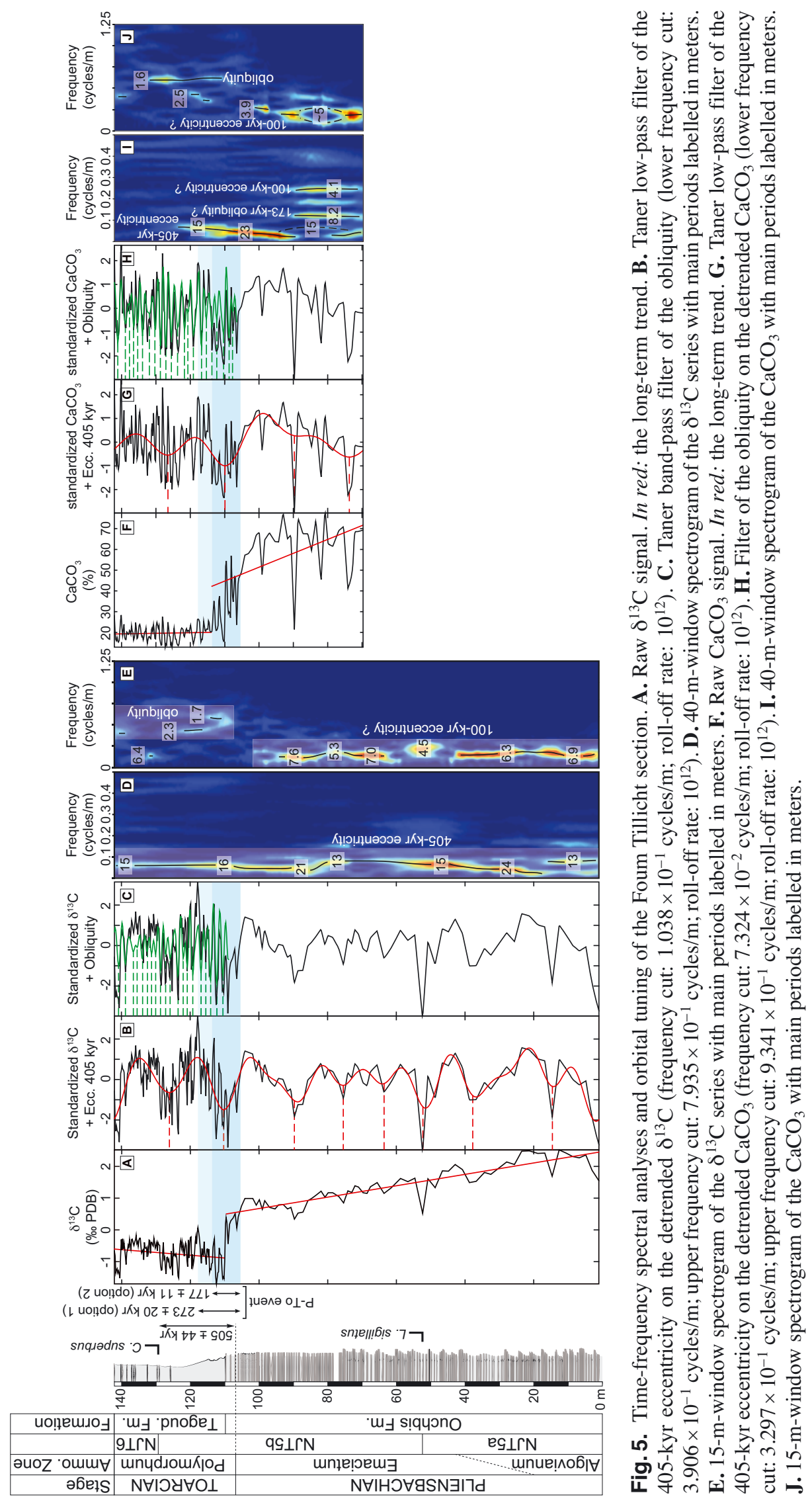


an even sample step, the series were linearly resampled every $0.20 \mathrm{~m}$ in order to allow the multi-taper method (MTM) to be applied to the series. Significance levels of spectral peaks were assessed using the LOWSPEC method (Meyers 2012), and the robust method of Mann and Lees (1996) modified in Meyers (2014). Time-frequency weighted fast Fourier transforms (TF-WFFT, e.g. Martinez et al. 2013, 2015) were then applied to constrain the evolution of the periods throughout the sedimentary series. A first TFWFFT was applied on 40-m width windows to better constrain the low frequencies, and a TF-WFFT on 20- $\mathrm{m}$ width windows was applied to focus on the evolution of the short periods. The cross multi-taper and the cross-phase spectra were also calculated between the $\delta^{13} \mathrm{C}_{\text {carb }}$ and $\mathrm{CaCO}_{3}$ signals using the algorithm developed in Huybers and Denton (2008) and provided in the following url link: http://www.people.fas.har vard.edu/ phuybers/Mfiles/

Taner low-pass and band-pass filters were then applied to isolate each signal interpreted as an orbital forcing. Orbital tuning procedures are then used to anchor the sedimentary cycles to their corresponding orbital periods, allowing depth-time conversions to be done. Here, minima of filtered series are used to define the anchor points. Between two anchor points, a duration of $405 \mathrm{kyr}$ or $34.9 \mathrm{kyr}$ is attributed, depending if the 405-kyr eccentricity or the main obliquity (34.9 kyr) are used to anchor the series. Within each repetition of the target cycle, a constant sedimentation rate is assumed. Above the last complete cycle or below the first complete cycle, the sedimentation rate is assumed to be the same as within the last or the first complete cycle, respectively. A relative age is thus attributed to each point. Durations are then estimated by calculating the difference of relative ages. Error margins are estimated by calculating the standard deviation of the duration estimates for each time interval.

\section{Results}

\subsection{Geochemical data}

\subsubsection{Inorganic carbon isotopes}

The carbon-isotope profile of the Foum Tillicht section can be divided into two chemostratigraphic intervals based on their specific pattern (Figs. 4, 5). The interval from $0 \mathrm{~m}$ to $110 \mathrm{~m}$ (Pliensbachian part of the series) is characterised by an overall decreasing trend of the $\delta^{13} \mathrm{C}_{\text {carb }}$ values from +2.5 to $+0.5 \%$. This trend is mod- ulated by regular $6-\mathrm{m}$ thick small amplitude $(0.5 \%)$ fluctuations of the $\delta^{13} \mathrm{C}_{\text {carb }}$ values. The interval from $110 \mathrm{~m}$ to $142.25 \mathrm{~m}$ (Toarcian part) records an increase of the $\delta^{13} \mathrm{C}_{\text {carb }}$ ratios from $-1 \%$ o to $-0.6 \%$. The trend is modulated by 2-m fluctuations of the $\delta^{13} \mathrm{C}_{\text {carb }}$ values, oscillating between $0 \%$ and $-2 \%$. The transition between the first and the second interval is abrupt and characterised by a sharp and prominent $2 \%$ decrease of the $\delta^{13} \mathrm{C}_{\text {carb }}$ values (Fig.4). This abrupt shift has been linked to the P-To event based on organic and inorganic carbon isotope chemostratigraphy constrained by ammonite and nannofossil biostratigraphy (Bodin et al. 2016). The top part of the second interval is also marked by a hiatus inferred from chemostratigraphic correlation (Bodin et al. 2016, see Fig. 4). Most likely this discontinuity is due to subaqueous erosion as supported by the overall deep marine environmental setting characterising the Foum Tillicht section and also the common occurrence of turbidite-rich interval above the base of the hiatus at $142.25 \mathrm{~m}$ (Fig. 4, Bodin et al. 2016).

\subsubsection{Carbonate contents}

As for the carbon isotopes, the carbonate content series can be divided into two intervals. The first interval of the series, from $69.7 \mathrm{~m}$ to $113.61 \mathrm{~m}$, shows a trend of $\mathrm{CaCO}_{3}$ values decreasing from $72 \%$ to $42 \%$ (Fig. $5 \mathrm{~F}$ ). Within this trend, high-amplitude fluctuations (20$50 \%$ ) are observed with a thickness of $4-6 \mathrm{~m}$. The transition from the first to the second interval is more progressive than observed for the $\delta^{13} \mathrm{C}_{\text {carb }}$ series. The values and high-frequency amplitudes of the $\mathrm{CaCO}_{3}$ series rapidly decrease from $105.38 \mathrm{~m}$ to $113.61 \mathrm{~m}$. This interval corresponds to the transition from the Ouchbis Formation and the Tagoudite Formation and is related to the P-To event (see section 2.2). The second interval, from $113.61 \mathrm{~m}$ to $142.25 \mathrm{~m}$, shows low values and rather stable values of $\mathrm{CaCO}_{3}$ around $20 \%$. High-frequency fluctuations are still observed but with much lower amplitudes compared to the first interval $(\sim 10 \%)$.

\subsection{Results from spectral analyses}

The $2 \pi$-MTM spectrum of the $\delta^{13} C_{\text {carb }}$ series shows significant bands at periods $17.6 \mathrm{~m}, 1.7 \mathrm{~m}$ (on average) and $0.9 \mathrm{~m}$ (Figs.6A, C, E). On spectrograms, the $\sim 17-\mathrm{m}$ peak is observed throughout the series, having periods evolving from $24 \mathrm{~m}$ to $13 \mathrm{~m}$ (Fig. 5D). The 15-m-width-window spectrogram (Fig.5E) shows, from the base of the series to level $102 \mathrm{~m}$, a band of periods ranging from $4.5 \mathrm{~m}$ to $7.6 \mathrm{~m}$. On the multi-taper 
spectrum, the amplitude of this cycle is not enough to exceed the 95\% confidence level (Fig. 6). From $107 \mathrm{~m}$ to the top of the series, the spectrogram shows a band of periods ranging from 2.3 to $1.7 \mathrm{~m}$ (Fig. 5E).

The $2 \pi$-MTM spectrum of the $\mathrm{CaCO}_{3}$ series shows significant bands of periods at $1.8 \mathrm{~m}$ on average and $0.9 \mathrm{~m}$ (Fig.6B, D, F). Another period at $18.2 \mathrm{~m}$ evolves from 15 to $23 \mathrm{~m}$ and displays high amplitudes from the levels $70 \mathrm{~m}$ to $124 \mathrm{~m}$ (Figs. 6B, 5I). On the 40-m-width-windows of the $\mathrm{CaCO}_{3}$, periods at $8.2 \mathrm{~m}$ and $4.1 \mathrm{~m}$ appear from the $70 \mathrm{~m}$ to $90 \mathrm{~m}$ (Fig. 5I). On the 15-m-width-windows of the $\mathrm{CaCO}_{3}$, a band of periods ranging from 5 to $3.9 \mathrm{~m}$ appears from levels $70 \mathrm{~m}$ to $102 \mathrm{~m}$ (Fig. 5J). Another band of periods ranging from 2.5 to $1.6 \mathrm{~m}$ appears from levels $110 \mathrm{~m}$ to the top of the series.

The cross-MTM analysis is performed with the $\delta^{13} \mathrm{C}_{\text {carb }}$ and $\mathrm{CaCO}_{3}$ signals that have been both linearly interpolated every $0.20 \mathrm{~m}$ from 69.7 to $142.1 \mathrm{~m}$ and standardised. Significant coherence values are observed between the two signals at $16.1 \mathrm{~m}$, a band of period centred on $1.7 \mathrm{~m}$ and a band of periods centred on $0.9 \mathrm{~m}$ (Fig. 7A). The average phase of these significantly coherent periods is $7^{\circ}$ (Fig. 7B). In addition, the phase lag observed for each significant frequency individually reaches the equivalent of twice the sample step for the 16-m period, and corresponds to a value lower than the sample step otherwise. The two signals are roughly in phase: the bulk $\delta^{13} \mathrm{C}_{\text {carb }}$ increases with increasing $\mathrm{CaCO}_{3}$ values. This is also shown with a simple cross-plot, in which the $\delta^{13} C_{\text {carb }}$ values of limestone beds are higher than the $\delta^{13} \mathrm{C}_{\text {carb }}$ values of marlstone beds (Fig. 7C).

\section{Discussion}

\subsection{Interpretation of the sedimentary cycles}

On the multi-taper spectrum of the $\delta^{13} \mathrm{C}_{\text {carb }}$ series, the three significant periods of $0.9 \mathrm{~m}, 1.7 \mathrm{~m}$ and $17.6 \mathrm{~m}$ display a ratios of periods of $1: 1.9: 19.6$, close to the period ratios between the precession (average period: $19.9 \mathrm{kyr}$ ), the obliquity (main period $34.9 \mathrm{kyr}$ ) and the $405 \mathrm{kyr}$ eccentricity cycles (ratios: $1: 1.8: 20.4)$. The average period of $4.8 \mathrm{~m}$, showing high amplitudes on the spectrogram (Fig.5D), has a period ratio of $1: 3.6$ with the period of $17.6 \mathrm{~m}, 1: 2.8$ with the period of $1.7 \mathrm{~m}$ and $1: 5.3$ with the period of $0.9 \mathrm{~m}$. This $4.8-\mathrm{m}$ period is likely related to the $100-\mathrm{kyr}$ eccentricity.
On the multi-taper spectrum of the $\mathrm{CaCO}_{3}$ series, the significant periods of $1.8 \mathrm{~m}$ and $0.9 \mathrm{~m}$ display a period ratio of $1: 2$ related to the period ratio between the obliquity and the precession cycles. The period of $18.2 \mathrm{~m}$ has a ratio of $1: 10$ with the period at $1.8 \mathrm{~m}$, and a ratio of $1: 20$ with the period of $0.9 \mathrm{~m}$. The $18.2-\mathrm{m}$ peak is likely related to the $405-\mathrm{kyr}$ eccentricity cycle. The peak at $4.1 \mathrm{~m}$ observed on the spectrograms has a period ratio of $1: 4.4$ with the $18.2-\mathrm{m}$ peak, $1: 2.3$ with the 1.8 -m peak and $1: 4.6$ with the $0.9-\mathrm{m}$ peak. This period of $4.1 \mathrm{~m}$ can be related to the 100-kyr eccentricity. Also observed on the spectrograms, the period of $8.2 \mathrm{~m}$ shows a ratio of $1: 2.2$ with the period of $18.2 \mathrm{~m}$, a ratio of $1: 2$ with the period of $4.1 \mathrm{~m}$ and a ratio of $1: 4.6$ with the period of $1.8 \mathrm{~m}$. This period of $8.2 \mathrm{~m}$ can be related to the $173-\mathrm{kyr}$ obliquity, a period shown in the astronomical solutions as an amplitude modulation of the obliquity cycles and related to $s 3-s 6$, the secular frequencies of the inclination of the Earth and Saturn orbits (Laskar et al. 2004, 2011).

In summary, the 405-kyr eccentricity is recorded on $17-18 \mathrm{~m}$ of sediment thickness, the 100-kyr eccentricity on 4.1-4.8 $\mathrm{m}$, the main obliquity on $1.7-1.9 \mathrm{~m}$ and the precession on $0.9 \mathrm{~m}$.

\subsection{Significance of the $\delta^{13} C_{\text {carb }}$ signal}

Cyclic fluctuations in the $\delta^{13} \mathrm{C}_{\text {carb }}$ record has been previously documented from the Cenozoic to the Jurassic archives, mostly related to the long ( $\geq 405 \mathrm{kyr}$ ) eccentricity and obliquity cycles (Zachos et al. 2001, Cramer et al. 2003, Pälike et al. 2006, Voigt et al. 2007, Wang et al. 2010, Giorgioni et al. 2012, Laurin et al. 2015, Martinez and Dera 2015). Several explanations have been brought forward by these authors in order to explain the transfer of the orbital forcing into the carbon isotope record, involving regional or global processes. Here, the long-term trend of the $\delta^{13} \mathrm{C}_{\text {carb }}$ curve obtained at Foum Tillicht fits neither with the long-term of the $\delta^{13} C_{\text {org }}$ curve from the same section (Fig.4), nor with other $\delta^{13} \mathrm{C}_{\text {carb }}$ curves obtained from the Northern Tethyan margin (see compilation in Pittet et al. 2014). This favours a basin-scale control of the $\delta^{13} \mathrm{C}_{\text {carb }}$, at least in part decoupled from organic carbon reservoirs.

The $\delta^{13} \mathrm{C}_{\text {carb }}$ and $\mathrm{CaCO}_{3}$ signals are significantly coherent and in phase at the Milankovitch band (Fig. 7). In other words, the $\delta^{13} C_{\text {carb }}$ is higher in limestone than in marl beds. Bodin et al. (2016) have notably noticed that the major negative shift in $\delta^{13} C_{\text {carb }}$ at the Pliensbachian-Toarcian transition was likely related to the demise of the neritic carbonate factory around the 

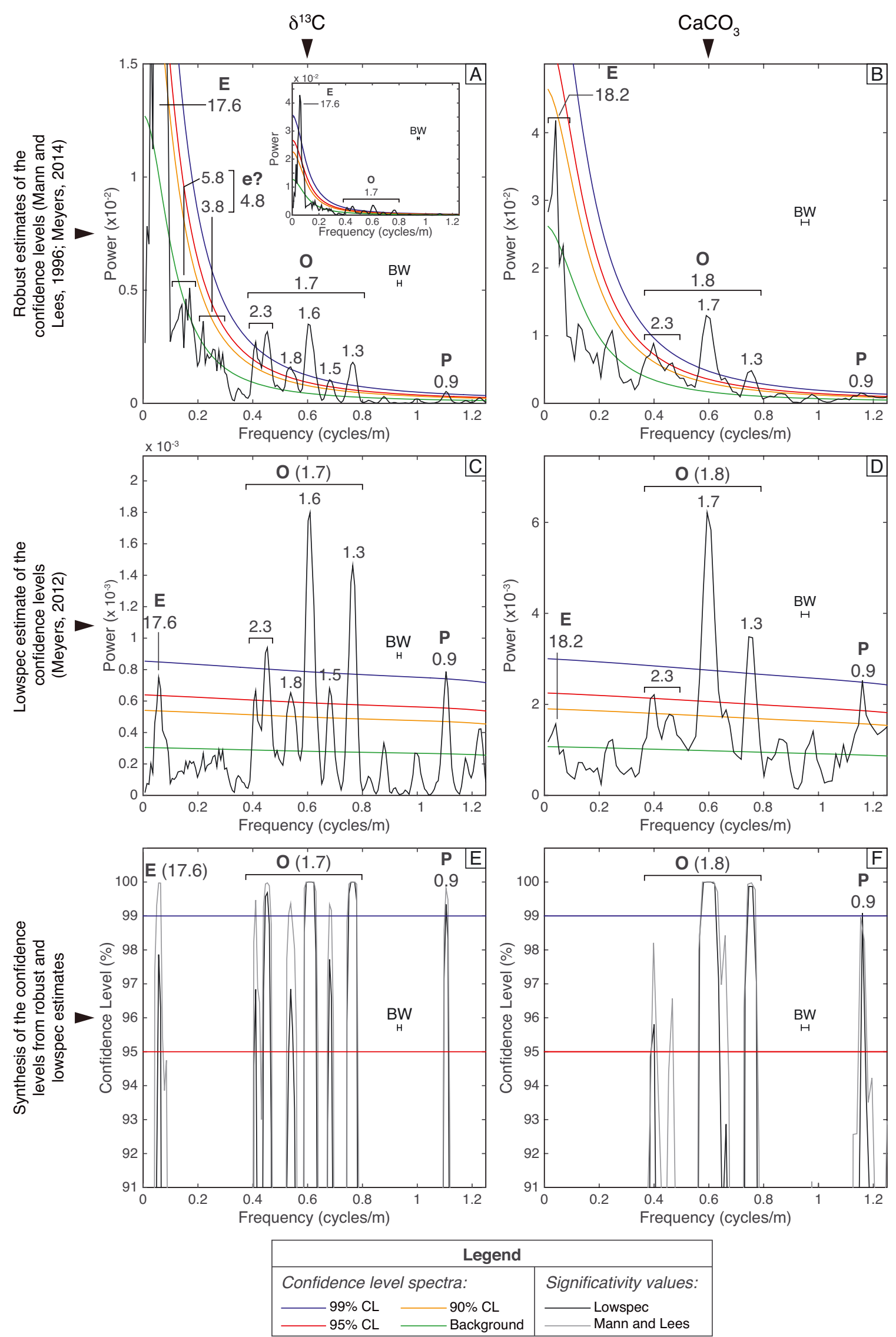

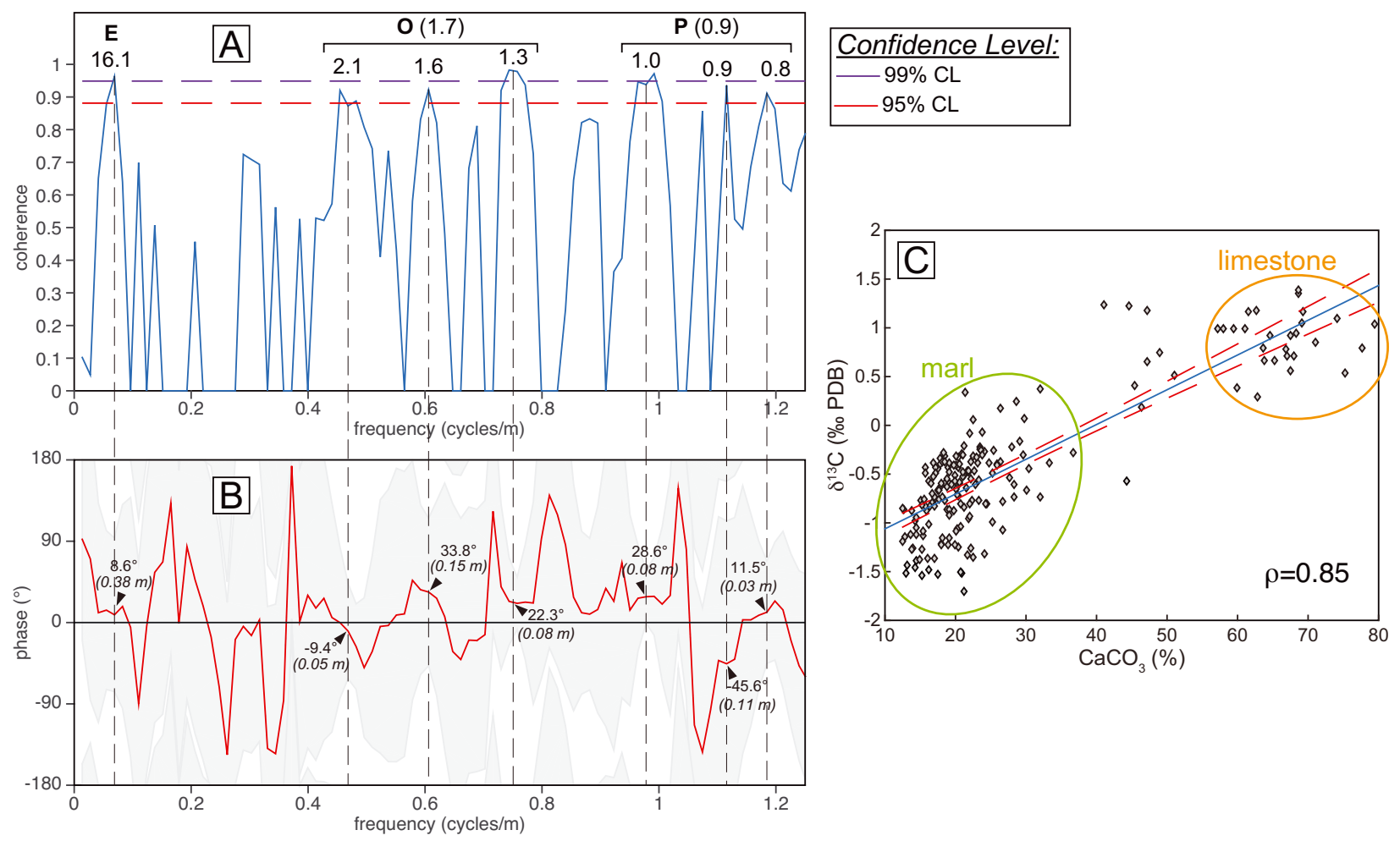

Fig. 7. Cross-MTM analysis and cross-plot of the $\delta^{13} \mathrm{C}$ and $\mathrm{CaCO}_{3}$ signals. A. Coherency spectrum. B. Cross-phase spectrum. The numbers in italic indicate the equivalent of the phase lag in meters. C. Cross-plot. The Q-value indicates the correlation coefficient. Notice that here the data set is divided in two groups, differentiated by their lithology, making the $Q$-value very high. The correlation coefficient is used here as a guide to show that the $\delta^{13} \mathrm{C}$ is higher in limestone beds than in marlstone beds.

High Atlas Basin, leading to a halt of neritic carbonate mud shedding into the basinal setting. In addition, carbonates in the Ouchbis Formation have high $\mathrm{Sr}$ contents, suggesting an aragonitic origin, in agreement with platform shedding (Wilmsen and Neuweiler 2008). Given that this neritic carbonate mud is likely enriched in ${ }^{13} \mathrm{C}$ compared to pelagic carbonates (Swart and Eberli 2005, Swart 2008, Oehlert et al. 2012), the mixing of neritic mud with pelagic ooze will tend to augment the bulk $\delta^{13} \mathrm{C}_{\text {carb }}$ signal in limestone beds.
Conversely, detrital and organic matter inputs from continental areas, associated to the deposit of marl beds, will tend to decrease the $\delta^{13} \mathrm{C}_{\text {carb }}$ values, as it has been shown in early stages of the Jurassic sedimentation in the Central High Atlas Basin (Wilmsen and Neuweiler 2008). In hemipealgic marl-limestone alternations, marls are commonly associated to higher levels of primary productivity associated to basin fertilization (Mutterlose and Ruffell 1999, Gréselle et al. 2011, Giraud et al. 2013), contributing in a reduction

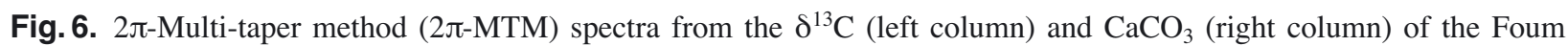
Tillicht section. A. $2 \pi$-MTM spectrum of the $\delta^{13} \mathrm{C}$ series, focused on the low powers. Inset: $2 \pi$-MTM spectrum showing the highest-power peaks. Confidence levels are calculated from the red-noise fit assessed with the robust method of Mann and Lees (1996) modified in the astrochron R package (Meyers 2014). B. $2 \pi-M T M$ spectrum of the $\mathrm{CaCO}_{3}$ series. Confidence levels are calculated from the red-noise fit assessed with the robust method modified in the astrochron $\mathrm{R}$ package. C. Prewhitened $2 \pi$-MTM spectrum of the $\delta^{13} \mathrm{C}$ series. Confidence levels are calculated from the red-noise fit assessed with the LOWSPEC method (Meyers 2012). D. Prewhitened 2 $\pi$-MTM spectrum of the $\mathrm{CaCO}_{3}$ series. Confidence levels are calculated from the red-noise fit assessed with the LOWSPEC method. E. Summary of confidence levels from the robust and LOWSPEC methods of the $\delta^{13} \mathrm{C}$ series F. Summary of confidence levels from the robust and LOWSPEC methods of the the $\mathrm{CaCO}_{3}$ series. Main periods are labelled in meters. BW: BandWidth. CL: Confidence Level. E: 405-kyr eccentricity; e: 100kyr eccentricity; O: main obliquity (34.9 kyr); P: mean precession (19.9 kyr). 
of the values in $\delta^{13} \mathrm{C}_{\text {carb }}$ marls. Partial remineralization of organic matter in the marly interval during burial might have also reinforced the initial contrast in $\delta^{13} \mathrm{C}_{\text {carb }}$ values at all Milankovitch bands.

It is worth noting that the sedimentation rate remains stable at the passage from the Ouchbis to the Tagoudite formations (Fig. 5). If marl-limestone alternations were only triggered by dilution effects by carbonate exports or detrital supplies, the passage to the Tagoudite Formation would respectively imply a strong decrease or increase in the sedimentation rate. The stability of the sedimentation rate from the Pliensbachian to the Toarcian implies that marl-limestone alternations reflect a balance between detrital supplies and carbonate shedding, linked to successive humid/ arid and sea-level fluctuations (see for instance Hoedemaeker 1998, Mutterlose and Ruffell 1999, Moiroud et al. 2012).

\subsection{Calibration of the Foum Tillicht section}

The 405-kyr eccentricity cycle has high amplitudes throughout the whole $\delta^{13} \mathrm{C}_{\text {carb }}$ series and high amplitudes in the $\mathrm{CaCO}_{3}$ series from levels $70 \mathrm{~m}$ to $124 \mathrm{~m}$, while the obliquity cycle shows high amplitudes in the densely sampled interval of the series (from $109 \mathrm{~m}$ to the top of the series, Fig. 5). Both obliquity and the 405kyr eccentricity are thus used for calibrating the series and estimating durations. For both proxies, two age models have been calculated (Table 1): one based on the 405-kyr eccentricity only, and one based on the obliquity in the densely sampled part of the series (from $109 \mathrm{~m}$ to the top of series) and on the 405-kyr eccentricity on the least densely sampled part of the series (from the base of the series to $109 \mathrm{~m}$ ). Spectral analyses on both series calibrated with the 405-kyr eccentricity reveal strong period at ca. $0.4 \mathrm{myr}$ - expected for a series calibrated with the 405-kyr cycle -, but also main periods at 41-42 kyr (associated with the obliquity), and from 25 to $16 \mathrm{kyr}$ (associated with the precession) (Fig. 8). Spectral analyses on both series calibrated with the 405-kyr eccentricity and the obliquity reveal strong powers for the 405-kyr band and the obliquity band - expected -, and significant peaks at $100 \mathrm{kyr}$, associated to the eccentricity, and from $24 \mathrm{kyr}$ to $14 \mathrm{kyr}$, associated to the precession (Fig. 8). The spectra of the series calibrated with only the 405-kyr eccentricity cycle reveal periods of 41-42 kyr for the obliquity, which is higher than the value predicted in the astronomical models for the Toarcian Stage (34.9 kyr; Laskar et al.
2004). This difference can be due to the existence of short-term hiati in the Toarcian part of the series, which decreases the number of obliquity cycles recorded per eccentricity cycle. This uncertainty impacts the duration estimates of the biozones. Another source of uncertainty exists at low frequencies and corresponds to the accuracy with which the limits of the 405-kyr cycles have been positioned. Differences thus exist in the duration estimate of a considered time interval from one age model to another. The difference between the average estimate and an extremum estimate reaches a maximum of 0.07 myr for the Polymorphum Zone (Table 1). In the following paragraph, the average duration estimates are given. Full range of duration estimates can be found in Table 1 .

The average duration estimate of the whole studied series is assessed at $3.41 \mathrm{myr}$, with estimates ranging from 3.35 myr to $3.47 \mathrm{myr}$ (Table 1). The duration of the P-To event, as defined in Bodin et al. (2016), is assessed at 0.27 myr (option 1 in Fig. 5), the duration of the interval from the base of the Toarcian to the FO of C.superbus at 0.51 myr (Fig. 5), and the minimum duration of the Polymorphum ammonite zone at 0.81 myr. In addition, in the Pliensbachian, the duration of the Emaciatum ammonite zone is assessed at $2.05 \pm 0.318$ myr. The error margin here reflects the uncertainty in the position of the lower boundary of this ammonite zone (Figs.3, 4). The minimum duration from the FO of L. sigillatus to the base of the Toarcian Stage is assessed at $1.55 \mathrm{Ma}$. Finally, the calcareous nannofossil Subzone NTJ5b, spanning the interval from the FO of L. sigillatus to the FO of C.superbus, has a minimum duration assessed here at 2.07 myr. The durations implying the FO of L. sigillatus are given as minimum values since the position of this FO is uncertain at Foum Tillicht. The durations of intervals of particular interests are discussed in the next sections.

\subsection{Stratigraphic extension and duration of the P-To event}

The P-To event is an episode of rapid environmental changes. It is associated with a transient warming event (Suan et al. 2008a), an acceleration of the rate of extinction in marine macrofauna (Caruthers et al. 2013), intensification of continental weathering (Bodin et al. 2010, Krencker et al. 2015, Brazier et al. 2015), widespread carbonate platform drowning (Dromart et al. 1996, Léonide et al. 2012, Bodin et al. 2016), and a negative excursion in the carbonate carbon isotopes, particularly well observed at Peniche (Hesselbo et al. 2007). 
Table 1 Summary of the duration assessments from the various age models. Note (a): the average duration corresponds to the average of the maximum and minimum extension of the Emaciatum Zone considering the uncertainty in the lower boundary of this zone. N.A.: not available.

\begin{tabular}{|c|c|c|c|c|c|}
\hline \multirow[t]{2}{*}{ Stratigraphic interval } & \multicolumn{2}{|c|}{ Orbital tuning on $\delta^{13} \mathrm{C}$} & \multicolumn{3}{|c|}{ Orbital tuning on $\mathrm{CaCO}_{3}$} \\
\hline & $\begin{array}{l}\text { Durations } \\
\text { based on } \\
405 \mathrm{kyr} \\
\text { only (myr) }\end{array}$ & $\begin{array}{l}\text { Durations } \\
\text { based on } \\
\text { combined } \\
405 \text { kyr and } \\
\text { obliquity } \\
\text { (myr) }\end{array}$ & $\begin{array}{l}\text { Durations } \\
\text { based on } \\
405 \mathrm{kyr} \\
\text { only (myr) }\end{array}$ & $\begin{array}{l}\text { Durations } \\
\text { based on } \\
\text { combined } \\
405 \text { kyr and } \\
\text { obliquity } \\
\text { (myr) }\end{array}$ & $\begin{array}{l}\text { Average } \\
\text { duration } \\
\text { (myr) }\end{array}$ \\
\hline Studied series & 3.47 & 3.35 & N.A. & N.A. & 3.41 \\
\hline $\begin{array}{l}\text { P-To Event - Option } 1 \\
\text { P-To Event - Option } 2 \\
\text { Base Toarcian to minimum } \delta^{13} \mathrm{C} \text { during P-To Event }\end{array}$ & $\begin{array}{l}0.29 \\
0.19 \\
0.12\end{array}$ & $\begin{array}{l}0.26 \\
0.17 \\
0.11\end{array}$ & $\begin{array}{l}0.29 \\
0.19 \\
0.12\end{array}$ & $\begin{array}{l}0.25 \\
0.17 \\
0.11\end{array}$ & $\begin{array}{l}0.27 \\
0.18 \\
0.12\end{array}$ \\
\hline $\begin{array}{l}\text { Polymorphum (minimum) } \\
\text { Base Emaciatum (maximum extension) } \\
\text { Base Emaciatum (minimum extension) }\end{array}$ & $\begin{array}{l}0.88 \\
2.27 \\
1.82\end{array}$ & $\begin{array}{l}0.76 \\
2.27 \\
1.82\end{array}$ & $\begin{array}{l}0.85 \\
\text { N.A. } \\
\text { N.A. }\end{array}$ & $\begin{array}{l}0.75 \\
\text { N.A. } \\
\text { N.A. }\end{array}$ & $\begin{array}{l}0.81 \\
2.05 \text { (a) }\end{array}$ \\
\hline $\begin{array}{l}\text { Base Toarcian to FO C.superbus } \\
\text { FO L. sigillatus to base Toarcian }\end{array}$ & $\begin{array}{l}0.55 \\
1.55\end{array}$ & $\begin{array}{l}0.47 \\
1.55\end{array}$ & $\begin{array}{l}0.53 \\
\text { N.A. }\end{array}$ & $\begin{array}{l}0.47 \\
\text { N.A. }\end{array}$ & $\begin{array}{l}0.51 \\
1.55\end{array}$ \\
\hline NJT5b & 2.11 & 2.03 & N.A. & N.A. & 2.07 \\
\hline
\end{tabular}

The P-To event starts with a significant increase in the marl-to-limestone ratio both observed in Morocco and in the Lusitanian basins (Elmi 2009, Bodin et al. 2010, 2016), and accompanied by a decrease in the $\delta^{13} \mathrm{C}_{\text {carb }}$ values (Pittet et al. 2014). The end of the P-To event shows various trends across the Tethyan and Subboreal areas. At Peniche, the end of the P-To event is marked by a return of the $\delta^{13} C_{\text {carb }}$ values to the pre-P-To trend (Hesselbo et al. 2007, Fig. 9). At Foum Tillicht, the $\delta^{13} \mathrm{C}_{\text {carb }}$ values remain low after the rapid decrease observed at $\sim 110 \mathrm{~m}$, and then show smooth, low-amplitude fluctuations (Figs. 5, 9). Bodin et al. (2016) tentatively positioned the end of the P-To event at Foum Tillicht at the local maximum of the $\delta^{13} \mathrm{C}_{\text {carb }}$ values at $117.81 \mathrm{~m}$ (Fig. 4). This suggestion is also reported in Fig. 9 as Option 1. Based on the various astrochronological frameworks provided here the duration of the P-To event would thus be assessed as 0.27 myr.

The local maximum of $\delta^{13} \mathrm{C}_{\text {carb }}$ values at $117.81 \mathrm{~m}$ occurs in a smooth, cyclic trend so that one can question whether or not the interval after the sharp decrease of the $\delta^{13} \mathrm{C}_{\text {carb }}$ values still belongs to the P-To event (Bodin et al. 2016). The P-To event corresponds to a crisis in the carbonate platform production marked by a sharp decrease in the $\delta^{13} \mathrm{C}_{\text {carb }}$ and in the wt $\% \mathrm{CaCO}_{3}$ values (Figs. 5, 9). This feature is observed at a region- al scale (Hesselbo et al. 2007, Suan et al. 2008a, Trecalli et al. 2012, Bodin et al. 2016). The decrease in $\mathrm{wt} \% \mathrm{CaCO}_{3}$ values ends at $113.81 \mathrm{~m}$. Above, the $\mathrm{wt} \%$ $\mathrm{CaCO}_{3}$ series has low amplitudes and never exceeds $30 \%$. The P-To event at Foum Tillicht can thus be defined as the transition interval from high-amplitude and high $\delta^{13} \mathrm{C}_{\text {carb }}$ and wt $\% \mathrm{CaCO}_{3}$ values to low-amplitude and low $\delta^{13} \mathrm{C}_{\text {carb }}$ and $\mathrm{wt} \% \mathrm{CaCO}_{3}$ values. According to this definition (Option 2; Fig.9) and taking into account the various astrochronological frameworks provided here, the P-To event would have a duration of 0.18 myr.

The decreasing trend of the $\delta^{13} \mathrm{C}_{\text {carb }}$ values closely matches the lithological changes in most of the different studied basins (Hesselbo et al. 2007, Trecalli et al. 2012, Pittet et al. 2014, Bodin et al. 2016), and the extension from the base of the P-To event to the minimum of the $\delta^{13} \mathrm{C}_{\text {carb }}$ values appears to be reliable for establishing regional correlations. In the Foum Tillicht section, this interval has a duration assessed at 0.12 myr (Table 1).

Detailed astrochronological frameworks were provided in the Peniche section at the PliensbachianToarcian boundary (Suan et al. 2008b, Huang and Hesselbo 2014), the GSSP of the Toarcian Stage (Rocha et al. 2016). The duration of the P-To event at Peniche 

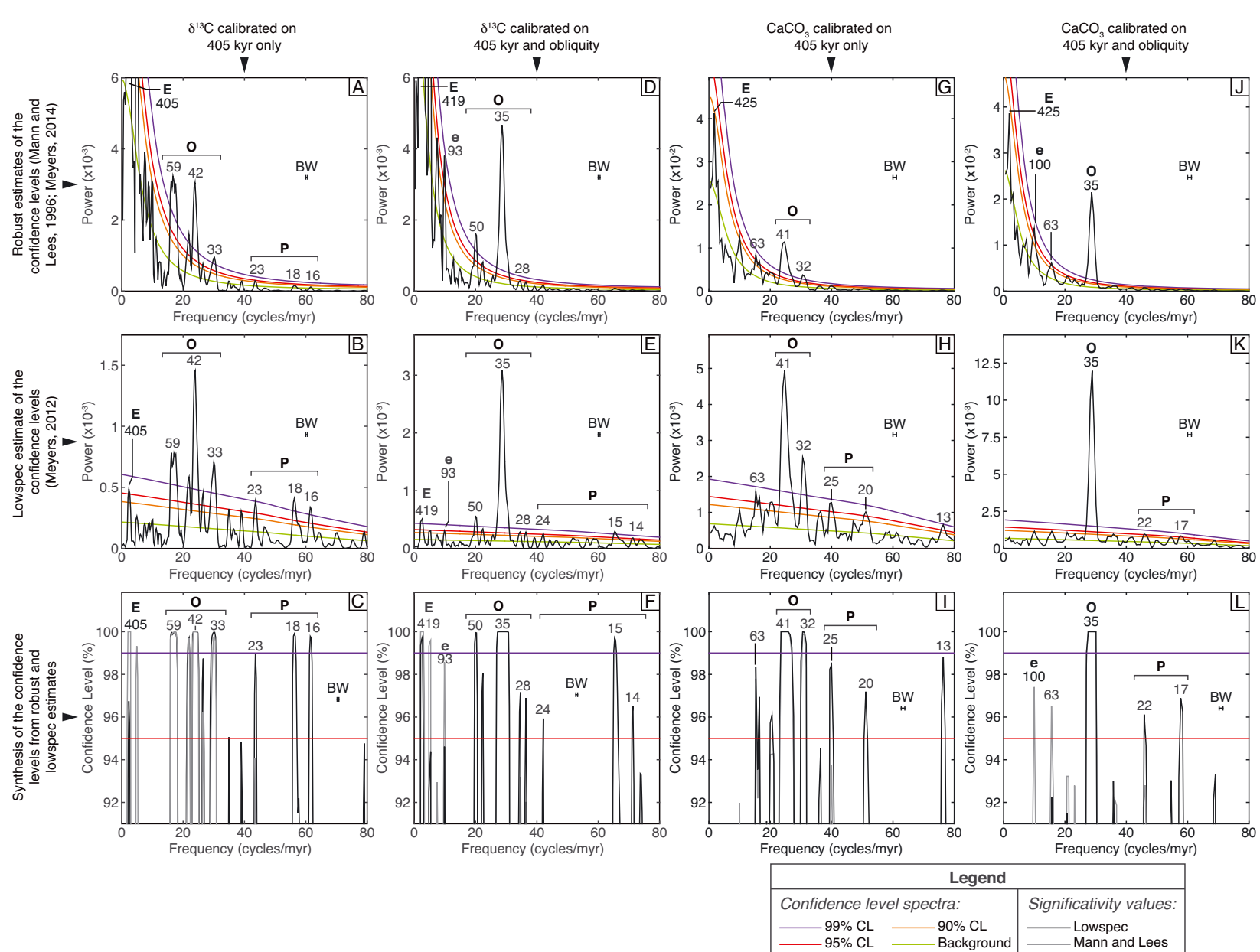

Fig. 8. $2 \pi$-MTM spectra of the $\delta^{13} \mathrm{C}$ and $\mathrm{CaCO}_{3}$ series after calibration based on the 405 -kyr eccentricity only and on the 405-kyr eccentricity and obliquity. The main periods are labelled in kyr. BW: BandWidth. E: 405-kyr eccentricity; e: 100kyr eccentricity; O: obliquity; P: precession.

could be deduced at 0.05 myr, while the duration from the base of the P-To event to the minimum of $\delta^{13} \mathrm{C}_{\text {carb }}$ values could be deduced at 0.04 myr. All these durations are significantly lower than the durations calculated at Foum Tillicht, suggesting a condensation in the Peniche section at the Pliensbachian-Toacian boundary, as already proposed by Pittet et al. 2014 (Discontinuity surface D1). This condensation will notably impact on the duration estimate of the Polymorphum/Tenuicostatum ammonite zone.

\subsection{Implication for the duration of the Polymorphum/Tenuicostatum Zone}

The recent astrochronological studies show diverging durations of the biozones and carbon-isotope excursion events in the Early Toarcian (Suan et al. 2008b, Kemp et al. 2011, Boulila et al. 2014, Huang and Hesselbo
2014, Ruebsam et al. 2014). Notably the duration of the first ammonite zone of the Toarcian (equivalent Polymorphum or Tenuicostatum Zone, see Figs. 2, 3) is highly uncertain, ranging from $0.09 \mathrm{myr}$ to $\sim 1.15 \mathrm{myr}$ (Mattioli and Pittet 2004, Boulila et al. 2014).

Using the 100-kyr-eccentricity cycle identified in Suan et al. (2008b), the duration of the Tenuicostatum Zone could be assessed at 0.82 myr. Using the $100-\mathrm{kyr}$ and the 405-kyr eccentricity identified in Huang and Hesselbo (2014) leads to a duration of 0.81 and 0.77 myr, respectively. From these astrochronological frameworks, an average duration of the Tenuicostatum Zone can be calculated as 0.80 myr. Minimum durations of the Tenuicostatum Zone were also reported at $>555 \mathrm{kyr}$ in the Lorraine sub-basin of the Paris Basin (core FR-210-78, Ruebsam et al. 2014), and at 0.09$0.5 \mathrm{myr}$ in the southern Paris Basin (Sancerre core, Boulila et al. 2014). In these two latter studies, the 


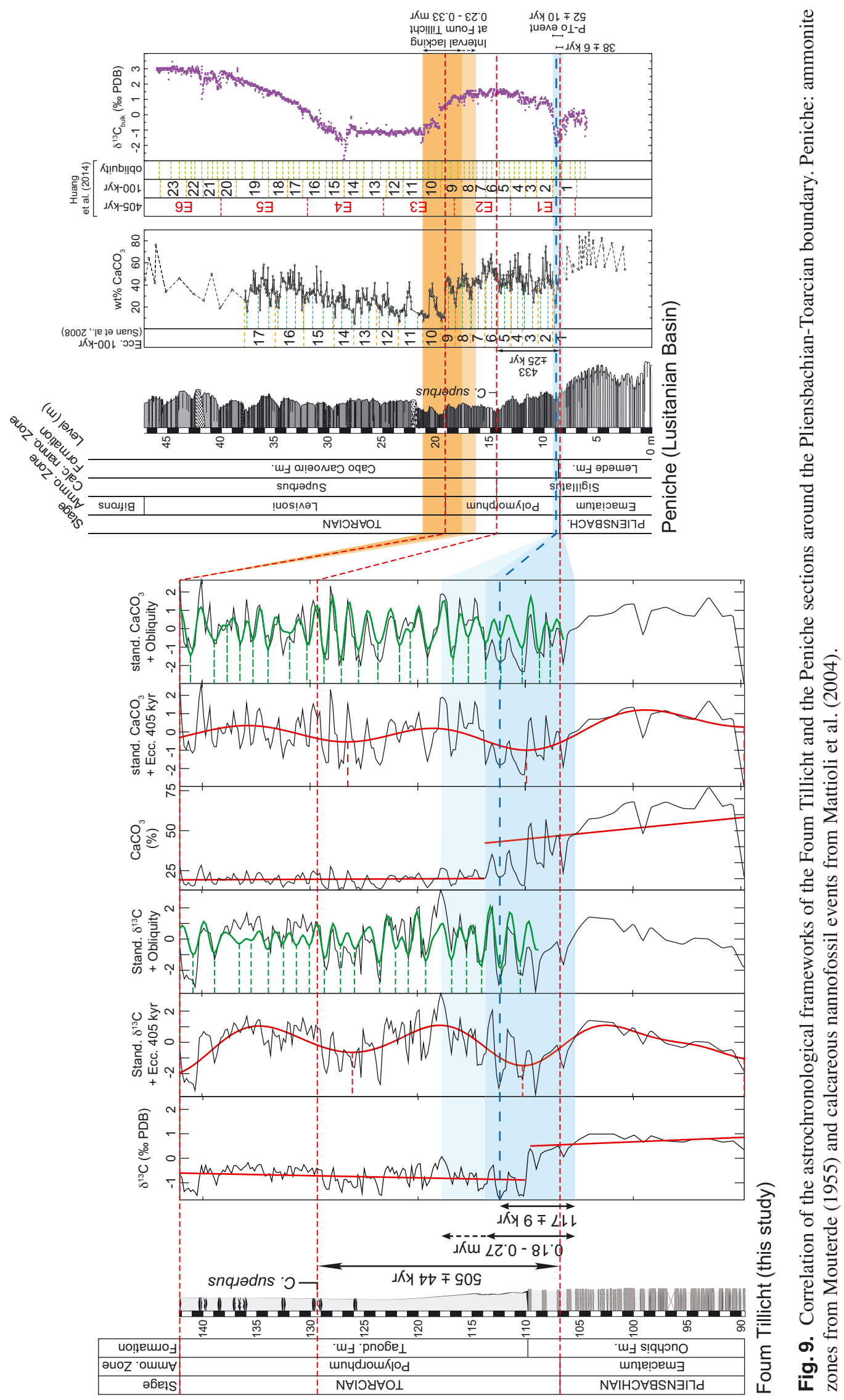


authors warned about the possibility of condensation or hiatus affecting the astrochronological framework inferred from these drill cores. In addition, significant biostratigraphic uncertainties exist at Sancerre on the position of lower and upper boundaries of the Tenuicostatum Zone (Boulila et al. 2014). In the Lorraine sub-basin, the FO of Dactylioceras tenuicostatum has not been formally recognised, the base of the Tenuicostatum Zone being positioned on the last occurrence of Pleuroceras spinatum (Guérin-Franiatte et al. 2010). Such biostratigraphic uncertainties are additional sources of errors in these duration estimates of the Tenuicostatum Zone. The GTS 2012 used the calibration of the Sancerre core to provide the duration of the Toarcian Stage, with an arbitrarily added duration to take into account possible condensation at Sancerre (Huang et al. 2010, Gradstein et al. 2012). The accurate duration estimate of the Tenuicostatum Zone is thus crucial to provide a reliable time scale for the Toarcian Stage.

The duration of the Polymorphum Zone calculated from the Foum Tillicht section is nonetheless a minimum duration since a hiatus is observed at the transition between the Polymorphum and the Levisoni zones, and also since a biostratigraphic condensation is potentially present at the transition between the Ouchbis and the Tagoudite Formations. The hiatus at the Polymorphum-Levisoni transition is notably at the base of a stratigraphic interval characterised by a sharp increase in the occurrence and thickness of turbidite levels. A sudden 5-\%o decrease of $\delta^{13} \mathrm{C}_{\text {org }}$ is observed throughout the Polymorphum-Levisoni transition, while other sections in the Central High Atlas Basin show a smoother initial decrease at the onset of the T-OAE (Bodin et al. 2016). Finally, $\delta^{13} \mathrm{C}_{\text {carb }}$ curves typically show a return to the pre-P-To values in the upper $1 / 3$ of the Polymorphum Zone, which is not observed in the Foum Tillicht section (Bodin et al. 2016).

Conversely, the Peniche section appears to have a short-term condensation at the Pliensbachian-Toarcian transition (Pittet et al. 2014), as also documented by the longer duration assessment found in the Foum Tillicht section. The Pliensbachian-Toarcian transition in the Peniche section is condensed by 0.1 to 0.2 myr, according to the various scenarios retained for the extension of the P-To event at Foum Tillicht. This implies a total duration of the Polymorphum/Tenuicostatum Zone ranging from 0.9 to $1.0 \mathrm{myr}$. Mattioli and Pittet (2004) identified in central Italy $\sim 11.5$ lithological sequences attributed to the $100-\mathrm{kyr}$ eccentricity in the Tenuicostatum Zone, implying a duration of
1.15 myr. In the Amellago section (Central High Atlas Basin), the return to the pre-P-To $\delta{ }^{13} \mathrm{C}_{\text {carb }}$ values (lacking at Foum Tillicht) covers $22 \mathrm{~m}$. With a sedimentation rate evaluated as $94 \mathrm{~m} / \mathrm{myr}$ for the early Toarcian (Bodin et al. 2016), this leads to a duration estimate of 0.23 myr. Although the visual identification of the sequences or the estimate of average sedimentation rates can lead to some errors, both observations support a long duration of the Polymorphum/Tenuicostatum Zone. The duration of 0.9-1.0 myr for this zoned agrees with the GTS 2012, who arbitrarily added 0.2 myr to the orbital chronology of Suan et al. (2008b). However, the integration of the orbital time scales of Foum Tillicht and Peniche show that this is a reasonable estimate.

\subsection{Implications for the FO of C. superbus}

In the GTS 2012, the first appearance of C.superbus in the Tethyan domain is aligned to its position in the Euro-Boreal domain, i.e. at the base of the Falciferum Zone (Gradstein et al. 2012). However, some discrepancies between authors have been reported (these additional comments can be found in Time Scale Creator 6.4, available at the following link: https://engi neering.purdue.edu/Stratigraphy/tscreator/index/index. php). In most of Euro-Boreal basins, including Yorkshire (Bucefalo Palliani et al. 2002, Boomer et al. 2009), and Northern Spain (Perilli 1999, 2000), the FO of $C$. superbus occurs either at the base or within the Serpentinum/Falciferum Zone (see Fig.2). Two noticeable exceptions are noted in the Euro-Boreal domain in the Asturias (Spain) and in Dotternhausen (Germany), in which the FO of C. superbus is located before the start of Serpentinum/Falciferum Zone (Mattioli et al. 2004, Fraguas et al. 2015). In the Peniche, Amellago and Foum Tillicht sections, the FO of C.superbus occurs in the middle part of the Tenuicostatum Zone. In Italy, the FO of C. superbus occurs below the black shale facies related to the T-OAE, and within the Tenuicostatum Zone, although the ammonite biostratigraphic scheme is flawed in Italy by the scarcity of ammonites within the black shale interval (Sabatino et al. 2009, Mattioli et al. 2013), obscuring the boundary between the Tenuicostatum and Serpentinus zones (Bilotta et al. 2010). The FO of C. superbus thus appears to occur earlier in most of Tethyan sections, i.e. below the T-OAE, than in most of Euro-Boreal sections where it occurs at the base or within the T-OAE (Mattioli and Erba 1999, Mailliot et al. 2006). 
In this study, the time interval from the base of the Polymorphum Zone to the FO of C.superbus is assessed at 0.51 myr (range: $0.47-0.53 \mathrm{myr}$ ) in the Foum Tillicht section, while this time interval has a duration assessment of 0.43 myr in the Peniche section (Fig. 9). Considering that the P-To boundary in the Peniche section is condensed by 0.1 to $0.2 \mathrm{myr}$, the duration from the base of the Toarcian to the FO of C.superbus at Peniche is re-evaluated as $0.53-0.63$ myr. The nannofossil assemblages have been analyzed at Foum Tillicht every $1.5 \mathrm{~m}$, which highlights the maximum uncertainty on the position of the FO of C.superbus. The average sedimentation rate of the Polymorphum Zone deduced from astrochronology is calculated at $44 \mathrm{~m} /$ myr, so that the uncertainty on the position of the FO of C. superbus at Foum Tillicht is assessed at 0.03 myr. Similarly, at Peniche, the nannofossil assemblages have been observed with a step of $0.4-0.5 \mathrm{~m}$, corresponding to an uncertainty of 0.04 myr. With this corrected evaluation and considering the error margins, the duration from the base of the Toarcian to the FO of C. superbus cannot be distinguished between Peniche and Foum Tillicht.

The GTS 2012 provides a zonation scheme of calcareous nannofossil from the Tethyan domain separated from the Euro-Boreal domain. Taking into account that (i) the FO of C.superbus occurs in the middle part of the Tenuicostatum/Polymorphum Zone in most of the Tethyan sections, and (ii) the duration between the base of the Toarcian and the FO of C.superbus ranges from 0.51 to 0.63 myr at Foum Tillicht and Peniche, we suggest placing the $\mathrm{FO}$ of $C$. superbus (and consequently the base of the NJT6 calcareous nannofossil Zone) in the Tethyan domain to $\sim 0.55 \mathrm{myr}$ after the beginning of the Tenuicostatum/Polymorphum Zone in the next compilation of the Geological Time Scale.

\subsection{Environmental disturbances during the P-To and its impact on the astrochronology of the Toarcian Stage}

The hiatus observed at the boundary between the Polymorphum and the Levisoni zones in the Foum Tillicht section represents a time span of $0.1-0.2$ myr. In addition, an interval of decreasing $\delta^{13} \mathrm{C}_{\text {carb }}$ values in lowermost part of the Levisoni Zone, is observed at Peniche and Amellago but is missing in the $\delta^{13} \mathrm{C}_{\text {org }}$ series at Foum Tillicht (Fig.4). By correlation with Peniche, this hiatus represents a total time of $0.23-0.33$ myr not preserved at Foum Tillicht. This time interval notably corresponds to the phase of gently decreasing $\delta^{13} \mathrm{C}$ values observed at the top of the Polymorphum Zone in bulk rock, belemnites and wood in the Peniche section (Hesselbo et al. 2007, Pittet et al. 2014). The $\delta^{13} \mathrm{C}_{\text {carb }}$ from the Foum Tillicht section cannot be directly compared with Peniche since it represents the local dynamics of the basin (Bodin et al. 2016), but the trends of the $\delta^{13} \mathrm{C}_{\text {org }}$ are less affected by mixing effect of $\delta^{13} \mathrm{C}$ from the carbonate platform and can thus be used for global correlations. The $\delta^{13} \mathrm{C}_{\text {org }}$ only shows the trend towards increasing values in the Tenuicostatum Zone, then sharply decrease by $7.5 \%$ at the hiatus level (Fig. 4). The phase of gently decreasing values of $\delta^{13} \mathrm{C}$ observed in the Peniche section from cycle 9 to cycle 10 is thus missing in the Foum Tillicht section. The stable trend of bulk rock and wood $\delta^{13} \mathrm{C}$ observed in the middle part of the Peniche section is not observed in the Foum Tillicht section (Figs. 4, 9, Hesselbo et al.2007). This phase starts below the FO of $C$.superbus and the fact that the $\mathrm{FO}$ of $C$. superbus is found in the middle part of the Polymorphum Zone in the Foum Tillicht section, as well as at Peniche, is incompatible with a hiatus spanning the whole second half of the Polymorphum Zone. This is rather linked to various trends in the $\delta^{13} \mathrm{C}$ values, as suggest the correlation of $\delta^{13} \mathrm{C}$ curves between Central High Atlas sections and Peniche (Bodin et al. 2010, 2016). The $\delta^{13} \mathrm{C}$ values from belemnite guards display at Peniche a similar trend as the $\delta^{13} \mathrm{C}_{\text {org }}$ from the Foum Tillicht section, with an increasing phase immediately followed by a gently decreasing phase lasting $\sim 0.15$ myr (Hesselbo et al. 2007), which is close to the trend of $\delta^{13} \mathrm{C}_{\text {org }}$ observed at Foum Tillicht.

The hiatus observed in the Foum Tillicht section spans the time interval from the upper part of the Polymorphum Zone to the lower Levisoni Zone (Fig.4). Two discontinuities have been defined within this time interval in the Lusitanian Basin, and then correlated throughout Euro-Boreal and Tethyan domains (Pittet et al. 2014, Ruebsam et al. 2014). Discontinuity D2 is an erosion surface that corresponds to the development of marine erosion in offshore environments as a consequence of a major sea-level drop, while discontinuity D3 is a condensed or non-deposition surface related to a major transgression. The merging of D2 and D3, as observed in the Foum Tillicht section and in some parts of the Lusitanian Basin, has been interpreted as the consequence of marine erosional processes during the sea-level drop followed by the development of a ravinement surface during the early phase of the following major transgression (Pittet et al. 2014). 
It is noteworthy that the Foum Tillicht section is not affected by phase D1 occurring at the PliensbachianToarcian boundary. This phase corresponds to a sequence condensed or lacking in multiple offshore sections due to basin starvation during a transgression event starting at the base of the Toarcian (Pittet et al. 2014). In contrast to European sections, the deep marine sections of the High Atlas Basin show expanded sedimentation rates. Higher nutrient levels and fluvialderived siliciclastic inputs were observed at the P-To boundary of shallow and deep marine sections, likely related to higher continental weathering (Bodin et al. 2010, Bodin et al. 2011, Krencker et al. 2015). Higher levels of detrital supply are indeed commonly observed with increase of continental weathering (Mutterlose and Ruffell 1999, Moiroud et al. 2012). As such, increasing levels of detrital supply at the P-To boundary would have thus provided sediment supply to deep-marine sections in the High-Atlas Basin, therefore preventing these sections from basin starvation.

\subsection{Further extensions in the Pliensbachian}

From the base of the series to $109.60 \mathrm{~m}$, two main bands of periods are observed, the first band ranging from $23 \mathrm{~m}$ to $13 \mathrm{~m}$ and the second from $7.6 \mathrm{~m}$ to $4.5 \mathrm{~m}$ (see the spectrograms on Fig. 5). These periods are attributed to the 405-kyr eccentricity and the 100-kyr eccentricity, although the band of period 7.6 to $4.5 \mathrm{~m}$ is under the confidence levels on the multi-taper spectrum (Fig. 6). The sample spacing in the Foum Tillicht section from the base of the succession to $109.60 \mathrm{~m}$ ranges from $0.35 \mathrm{~m}$ to $2.75 \mathrm{~m}$ with an average of $1.5 \mathrm{~m}$, which limits the exploration of the high frequencies. Considering the sampling density in this interval, the band of 100-kyr eccentricity contains $\sim 3-4$ samples per 100-kyr eccentricity which is not enough to accurately observe the amplitude of the 100-kyr cycle. Notably 4 to 10 samples per cycle are needed to accurately describe the amplitude of a cycle, otherwise the amplitude of the targeted cycle should be diminished and its frequency affected (Herbert 1994, Martinez et al. 2016). The only cycle correctly described from the base of the series to $109.37 \mathrm{~m}$ is the cycle attributed to the 405-kyr eccentricity.

The recognition of the 405-kyr eccentricity cycle in this part of the series allows significant differences with the GTS 2012 to be observed in the biozone durations. In the Pliensbachian part of the series, the FO of Lotharingius sigillatus is observed at least $1.55 \mathrm{myr}$ before the base of the Toarcian Stage. The GTS 2012 positions this event at the base of the Tenuicostatum ammonite Zone, following the biochronostratigraphic chart in Hardenbol et al. (1998) (details can be found in Time Scale Creator 6.4). Mattioli and Erba (1999) noticed sporadic occurrence of L. sigillatus in the Late Pliensbachian. In the Lusitanian Basin and in Northern Spain, the FO of L.sigillatus is reported within the Spinatum/Emaciatum Zone (Reggiani et al. 2010, Mattioli et al. 2013, Fraguas et al. 2015, Fig. 2). As for the FO of C.superbus, it appears with these new data that there is a mismatch between the bioevents from biostratigraphic data and the bioevents reported in the GTS 2012 (Figs. 2, 3). Consequently, the average duration of the NJT5b Subzone assessed here at $2.07 \mathrm{myr}$ is much longer than the 1.07 -myr duration of the NJT5b Subzone reported in the GTS 2012 (Gradstein et al. 2012). Due to the sampling density of nannofossil assemblage analyses, the position of the FO of L. sigillatus shows an uncertainty of at least $16.4 \mathrm{~m}$, which represents a time span of 0.43 myr. The orbital chronology provided in the Foum Tillicht section nonetheless shows that the duration of the NJT5b is significantly underestimated in the GTS 2012.

Other differences are observed in the duration estimates of the Emaciatum Zone and the Spinatum Zone. The duration estimated here for the Emaciatum Zone is $2.044 \pm 0.318 \mathrm{myr}$, the uncertainty being related to the uncertainty of the position of the base of the Emaciatum Zone (Fig. 4). Conversely, the GTS 2012 provides a duration estimate of the Emaciatum Zone of 0.79 myr (Gradstein et al. 2012). Ammonite-zone durations of the Late Pliensbachian are based on the recognition of the precession in Italy and England, providing a minimum duration of the Spinatum Zone, then constrained on a linear trend of Sr-isotope ratios from the Hettangian to the Pliensbachian (Weedon and Jenkyns 1999, Weedon et al. 1999). In the GTS 2012, the base of the Emaciatum Zone was then located on the upper third of the Apyrenum Subzone, the first subzone of Spinatum Zone (Hardenbol et al. 1998, Gradstein et al. 2012). This approach has, at least, three weaknesses. Correlations between the Emaciatum and the Spinatum zones are still unclear due to a strong provincialism between Mediterranean and Euro-boreal faunas (Dera et al. 2011b), the calibration based on precession cycles can easily be affected by short-term hiatuses (Weedon and Jenkyns 1999), and the trend of Sr-isotope in not necessarily linear. Environmental conditions, such as modifications in the levels of continental weathering, can modify the rate of 
change of Sr-isotope ratios at a time scale of $\sim 10^{0} \mathrm{myr}$ (McArthur et al. 2007, Kemp et al. 2011, Bodin et al. 2015). Notably, orbital calibrations of ammonite zones can lead to higher or lower durations compared to durations calculated by linear trend of Sr-isotope ratios (e. g. Martinez et al. 2012).

\section{Conclusions}

A new orbital chronology is provided for the Pliensbachian-Toarcian transition, performed for the first time in the expanded hemipelagic section of Foum Tillicht from the Central High Atlas Basin (Morocco). Based on the recognition of the obliquity and 405-kyr eccentricity cycles, and correlations with European sections, the duration of the Polymorphum Zone could be evaluated as $0.9-1.0 \mathrm{myr}$, while the duration of the P-To event is estimated as 0.18-0.27 myr. By correlating the orbital time scales from the Foum Tillicht and the Peniche sections, the condensation phase D1 have affected a time span of $0.1-0.2$ myr of sediment, while the time missing at Foum Tillicht at the Polymorphum-Levisoni boundary is assessed as $0.23-$ 0.33 myr. Although the orbital chronology of both sections is impacted by the major environmental changes recorded in the Early Toarcian, an integrated approach decreased the impact of local hiati or condensed intervals on the construction of the orbital time scale. Finally, the record of the 405-kyr eccentricity cycle in the Pliensbachian part of the series allowed the average minimum duration of the NJ5b calcareous nannofossil zone to be assessed at $2.07 \mathrm{myr}$, while the duration of the Emaciatum zone is estimated as $2.05 \pm$ 0.32 myr. Although weak biostratigraphic control on the Pliensbachian part of the series affects the two latter durations, these are significantly longer than in the Geological Time Scale 2012, and highlight the potential of the expanded sections of the High Atlas Basin to provide a reliable orbital time scale of the Pliensbachian Stage.

Acknowledgements. Mathieu Martinez is supplied by European Research Council (ERC) Consolidated Grant EarthSequencing. Stéphane Bodin and François-Nicolas Krencker are supplied by the Deutsche Forschungsgemeinschaft (DFG, project ${ }^{\circ}$ BO 3655/1-1). We would like to thank Prof. André Strasser, Dr. Markus Wilmsen and an anonymous reviewer for their very constructive and positive comments. Will Brocas is also acknowledged for Englishproof reading, as well as Dr. Jochen Erbacher for having edited the manuscript.

\section{References}

Bassoulet, J., Poisson, A., Elmi, S., Cecca, F., Bellion, Y., Guiraud, R., Le Nindre, J., Manivit, J., 1993. Middle Toarcian paleoenvironments, carte à 1/20000000. In: Dercourt, J., Ricou, L.-E., Vrielynck, B. (Eds.), Atlas Tethys, palaeoenvironmental maps. BEICIP-FRANLAB, Rueil-Malmaison, France, 63-80.

Bassoullet, J.-P. and Baudin, F., 1994. Le Toarcien inférieur: une période de crise dans les bassins et sur les plateformes carbonatées de l'Europe du Nord-Ouest et de la Téthys. Geobios 17, 645-654.

Bilotta, M., Venturi, F., Sassaroli, S., 2010. Ammonite faunas, OAE and the Pliensbachian-Toarcian boundary (Early Jurassic) in the Apennines. Lethaia 43, 357380 .

Bodin, S., Fröhlich, S., Boutib, L., Lahsini, S., Redfern, J., 2011. Early Toarcian source-rock potential in the Central High Atlas Basin (central Morocco): regional distribution and depositional model. Journal of Petroleum Geology 34, 345-363.

Bodin, S., Krencker, F.-N., Kothe, T., Hoffmann, R., Mattioli, E., Heimhofer, U., Lahcen, K., 2016. Perturbation of the carbon cycle during the late Pliensbachian-early Toarcian: New insight from high-resolution carbon isotope records in Morocco. Journal of African Earth Sciences 116, 89-104.

Bodin, S., Mattioli, E., Fröhlich, S., Marshall, J.D., Boutib, L., Lahsini, S., Redfern, J., 2010. Toarcian carbon isotope shifts and nutrient changes from the Northern margin of Gondwana (High Atlas, Morocco, Jurassic): Palaeoenvironmental implications. Palaeogeography, Palaeoclimatology, Palaeoecology 297, 377-390.

Bodin, S., Meissner, P., Janssen, N. M. M., Steuber, T., Mutterlose, J., 2015. Large igneous provinces and organic carbon burial: Controls on global temperature and continental weathering during the Early Cretaceous. Global and Planetary Change 133, 238-253.

Boomer, I., Lord, A., Page, K., Bown, P., Lowry, F., Riding, J. B., 2009. The biostratigraphy of the Upper Pliensbachian-Toarcian (Lower Jurassic) sequence at Ilminster, Somerset. Journal of Micropalaeontology 28, 67-85.

Boulila, S., Galbrun, B., Huret, E., Hinnov, L. A., Rouget, I., Gardin, S., Bartolini, A., 2014. Astronomical calibration of the Toarcian Stage: Implications for sequence stratigraphy and duration of the early Toarcian OAE. Earth and Planetary Science Letters 386, 98-111.

Bown, P. and Cooper, M., 1998. Jurassic. In: Bown, P. (Eds.), Calcareous nannofossil biostratigraphy. Kluwer Academy, London, 34-85.

Brazier, J.-M., Suan, G., Tacail, T., Simon, L., Martin, J.E., Mattioli, E., Balter, V., 2015. Calcium isotope evidence for dramatic increase of continental weathering during the Toarcian oceanic anoxic event (Early Jurassic). Earth and Planetary Science Letters 411, 164-176.

Bucefalo Palliani, R., Mattioli, E., Riding, J.B., 2002. The response of marine phytoplankton and sedimentary organic matter to the early Toarcian (Lower Jurassic) 
oceanic anoxic event in northern England. Marine Micropaleontology 46, 223-245.

Cariou, E. and Hantzpergue, P., 1997. Biostratigraphie du Jurassique ouest-européen et méditerranéen: zonations parrallèles et distribution des invertébrés et microfossiles. Bulletin des Centres de Recherches Exploration-Production Elf Aquitaine, Mémoire 17, 422 pp.

Caruthers, A.H., Smith, P.L., Gröcke, D.R., 2013. The Pliensbachian-Toarcian (Early Jurassic) extinction, a global multi-phased event. Palaeogeography, Palaeoclimatology, Palaeoecology 386, 104-118.

Cohen, A. S., Coe, A. L., Harding, S. M., Schwark, L., 2004. Osmium isotope evidence for the regulation of atmospheric $\mathrm{CO}_{2}$ by continental weathering. Geology 32, 157160.

Cramer, B.S., Wright, J. D., Kent, D. V., Aubry, M.P., 2003. Orbital climate forcing of $\delta^{13} \mathrm{C}$ excursions in the late Paleocene-early Eocene (chrons C24n-C25n). Paleoceanography 18, 1097.

De Graciansky, P.-C., Dardeau, G., Dommergues, J.-L., Durlet, C., Marchand, D., Dumont, T., Hesselbo, S.P., Jacquin, T., Goggin, V., Meister, C., Mouterde, R., Rey, J., Vail, P.R., 1998. Ammonite biostratigraphic correlation and Early Jurassic sequence stratigraphy in France: comparisons with some UK sections. In: de Graciansky, P.-C., Hardenbol, J., Jacquin, T., Vail, P. R. (Eds.), Mesozoic and Cenozoic Sequence Stratigraphy of European Basins. 60, SEPM Special Publications, Tulsa, OK, USA, $583-622$.

De Vleeschouwer, D., Parnell, A.C., 2014. Reducing timescale uncertainty for the Devonian by integrating astrochronology and Bayesian statistics. Geology 42, 491-494.

Dera, G., Brigaud, B., Monna, F., Laffont, R., Puceat, E., Deconinck, J. F., Pellenard, P., Joachimski, M. M., Durlet, C., 2011a. Climatic ups and downs in a disturbed Jurassic world. Geology 39, 215-218.

Dera, G., Neige, P., Dommergues, J.-L., Brayard, A., 2011 b. Ammonite paleobiogeography during the PliensbachianToarcian crisis (Early Jurassic) reflecting paleoclimate, eustasy, and extinctions. Global and Planetary Change 78, 92-105.

Dera, G., Pellenard, P., Neige, P., Deconinck, J.-F., Pucéat, E., Dommergues, J.-L., 2009. Distribution of clay minerals in Early Jurassic Peritethyan seas: Palaeoclimatic significance inferred from multiproxy comparisons. Palaeogeography, Palaeoclimatology, Palaeoecology 271, 39-51.

Dromart, G., Allemand, P., Garcia, J.-P., Robin, C., 1996. Variation cyclique de la production carbonatée au Jurassique le long d'un transect Bourgogne-Ardèche, EstFrance. Bulletin de la Société géologique de France 167, 423-433.

Du Dresnay, R., 1971. Extension et développement des phénomènes récifaux jurassiques dans le domaine atlasique marocain, particulièrement au Lias moyen. Bulletin de la Société géologique de France 46-56.

Elmi, S., 2009. Pliensbachian-Toarcian boundary - the proposed GSSP of Peniche. Ciências da Terra (UNL) 16, 716.
Fraguas, Á., Comas-Rengifo, M.J., Perilli, N., 2015. Calcareous nannofossil biostratigraphy of the Lower Jurassic in the Cantabrian Range (Northern Spain). Newsletters on Stratigraphy 48, 179-199.

Frizon de Lamotte, D., Zizi, M., Missenard, Y., Hafid, M., El Azzouzi, M., Maury, R.C., Charrière, A., Taki, Z., Benammi, M., Michard, A., 2008. The Atlas System. In: Michard, A., Saddiqi, O., Chalouan, A., Frizon de Lamotte, D. (Eds.), Continental Evolution: The Geology of Morocco. Lecture Notes in Earth Sciences, 116, SpringerVerlag, Berlin, 133-202.

Giorgioni, M., Weissert, H., Bernasconi, S.M., Hochuli, P.A., Coccioni, R., Keller, C.E., 2012. Orbital control on carbon cycle and oceanography in the mid-Cretaceous greenhouse. Paleoceanography 27, PA1204.

Giraud, F., Reboulet, S., Deconinck, J.-F., Martinez, M., Carpentier, A., Bréziat, C., 2013. The Mid-Cenomanian Event in southeastern France: Evidence from palaeontological and clay mineralogical data. Cretaceous Research 46, 43-58.

Gradstein, F.M., Ogg, J.G., Schmitz, M., Ogg, G., 2012. The Geologic Time Scale 2012. Elsevier B. V., pp. 1176.

Gréselle, B., Pittet, B., Mattioli, E., Joachimski, M., Barbarin, N., Riquier, L., Reboulet, S., Pucéat, E., 2011. The Valanginian isotope event: A complex suite of palaeoenvironmental perturbations. Palaeogeography, Palaeoclimatology, Palaeoecology 306, 41-57.

Guérin-Franiatte, S., Maquil, R., Münzberger, P., 2010. Le Toarcien au Grand-Duché de Luxembourg: Biostratigraphie dans la région de Belvaux. In: Weis, R. and GuérinFraniatte, S. (Eds.), Le Jurassique inférieur et moyen au Luxembourg. Ferrantia, 62, Musée national d'histoire naturelle Luxembourg, Luxembourg, 19-34.

Hardenbol, J., Thierry, J., Farley, M. B., Jacquin, T., de Graciansky, P.-C., Vail, P.R., 1998. Mesozoic and Cenozoic Sequence Stratigraphic Framework of European Basins. In: de Graciansky, P.-C., Hardenbol, J., Jacquin, T., Vail, P.R. (Eds.), Mesozoic and Cenozoic Sequence Stratigraphy of European Basins. 60, SEPM Special Publications, Tulsa, OK, USA, 3-13.

Hoedemaeker, P.J., 1998. Berriasian-Barremian sequences in the Río Argos succession near Caravaca (Southeast Spain), and their correlation with some sections in Southeast France. In: de Graciansky, P.-C., Hardenbol, J., Jacquin, T., Vail, P.R. (Eds.), Mesozoic and Cenozoic Sequence Stratigraphy of European Basins. SEPM Special Publications 60, Society for Sedimentary Geology, Tulsa, USA, pp. 423-441.

Herbert, T.D., 1994. Reading orbital signals distorted by sedimentation: models and examples. In: de Boer, P.L. and Smith, D.G. (Eds.), Orbital Forcing and Cyclic Sequences. 19, SEPM Special Publications, Tulsa, OK, USA, 483-507.

Hesselbo, S.P., 2008. Sequence stratigraphy and inferred relative sea-level change from the onshore British Jurassic. Proceedings of the Geologists' Association 119, 19-34.

Hesselbo, S.P. and Jenkyns, H.C., 1998. British lower Jurassic sequence stratigraphy. In: de Graciansky, P.C., 
Hardenbol, J., Jacquin, T., Vail, P.R. (Eds.), Mesozoic and Cenozoic Sequence Stratigraphy of European Basins. 60, SEPM Special Publications, Tulsa, OK, USA, 561581.

Hesselbo, S.P., Jenkyns, H.C., Duarte, L. V., Oliveira, L.C. V., 2007. Carbon-isotope record of the Early Jurassic (Toarcian) Oceanic Anoxic Event from fossil wood and marine carbonate (Lusitanian Basin, Portugal). Earth and Planetary Science Letters 253, 455-470.

Huang, C. and Hesselbo, S.P., 2014. Pacing of the Toarcian Oceanic Anoxic Event (Early Jurassic) from astronomical correlation of marine sections. Gondwana Research 25, $1348-1356$.

Huang, C., Hinnov, L., Ogg, J., Galbrun, B., Boulila, S., Huret, E., 2010. Astronomical calibration of the Jurassic time scale. Earth Science Frontiers 17, 108-109.

Huybers, P. and Denton, G., 2008. Antarctic temperature at orbital timescales controlled by local summer duration. Nature Geoscience 1, 787-792.

Jenkyns, H.C., 1988. The early Toarcian (Jurassic) anoxic event; stratigraphic, sedimentary and geochemical evidence. American Journal of Science 288, 101-151.

Jenkyns, H.C., 2003. Evidence for rapid climate change in the Mesozoic-Palaeogene greenhouse world. Philosophical Transactions of the Royal Society of London A: Mathematical, Physical and Engineering Sciences 361, 1885-1916

Kemp, D. B., Coe, A.L., Cohen, A. S., Weedon, G.P., 2011. Astronomical forcing and chronology of the early Toarcian (Early Jurassic) oceanic anoxic event in Yorkshire, UK. Paleoceanography 26, PA4210.

Korte, C. and Hesselbo, S. P., 2011. Shallow marine carbon and oxygen isotope and elemental records indicate icehouse-greenhouse cycles during the Early Jurassic. Paleoceanography 26, PA4219.

Krencker, F.-N., Bodin, S., Suan, G., Heimhofer, U., Kabiri, L., Immenhauser, A., 2015. Toarcian extreme warmth led to tropical cyclone intensification. Earth and Planetary Science Letters 425, 120-130.

Krencker, F.-N., Bodin, S., Hoffmann, R., Suan, G., Mattioli, E., Kabiri, L., Föllmi, K. B., Immenhauser, A., 2014. The middle Toarcian cold snap: Trigger of mass extinction and carbonate factory demise. Global and Planetary Change 117, 64-78.

Laskar, J., Fienga, A., Gastineau, M., Manche, H., 2011. La2010: a new orbital solution for the long-term motion of the Earth. Astronomy \& Astrophysics 532, A89.

Laskar, J., Robutel, P., Joutel, F., Gastineau, M., Correia, A.C.M., Levrard, B., 2004. A long-term numerical solution for the insolation quantities of the Earth. Astronomy and Astrophysics 428, 261-285.

Laurin, J., Meyers, S.R., Uličný, D., Jarvis, I., Sageman, B.B., 2015. Axial obliquity control on the greenhouse carbon budget through middle- to high-latitude reservoirs. Paleoceanography 30, 133-149.

Léonide, P., Floquet, M., Durlet, C., Baudin, F., Pittet, B., Lécuyer, C., 2012. Drowning of a carbonate platform as a precursor stage of the Early Toarcian global anoxic event (Southern Provence sub-Basin, South-east France). Sedimentology 59, 156-184.

Little, C. T. and Benton, M.J., 1995. Early Jurassic mass extinction: a global long-term event. Geology 23, 495-498.

Lourens, L., Hilgen, F., Shackleton, N., Laskar, J., Wilson, D., 2004. The Neogene Period. In: (Eds.), A geologic time scale 2004. 409-440.

Mailliot, S., Mattioli, E., Guex, J., Pittet, B., 2006. The Early Toarcian anoxia, a synchronous event in the Western Tethys? An approach by quantitative biochronology (Unitary Associations), applied on calcareous nannofossils. Palaeogeography, Palaeoclimatology, Palaeoecology 240, 562-586.

Mann, M.E. and Lees, J.M., 1996. Robust estimation of background noise and signal detection in climatic time series. Climatic Change 33, 409-445.

Martinez, M., Deconinck, J.-F., Pellenard, P., Reboulet, S., Riquier, L., 2013. Astrochronology of the Valanginian Stage from reference sections (Vocontian Basin, France) and palaeoenvironmental implications for the Weissert Event. Palaeogeography, Palaeoclimatology, Palaeoecology 376, 91-102.

Martinez, M., Deconinck, J.-F., Pellenard, P., Riquier, L., Company, M., Reboulet, S., Moiroud, M., 2015. Astrochronology of the Valanginian-Hauterivian stages (Early Cretaceous): Chronological relationships between the Paraná-Etendeka large igneous province and the Weissert and the Faraoni events. Global and Planetary Change 131, 158-173.

Martinez, M. and Dera, G., 2015. Orbital pacing of carbon fluxes by a 9-My eccentricity cycle during the Mesozoic. Proceedings of the National Academy of Sciences of the United States of America 112, 12604-12609.

Martinez, M., Kotov, S., De Vleeschouwer, D., Pas, D., Pälike, H., 2016. Testing the impact of stratigraphic uncertainty on spectral analyses of sedimentary time series. Climate of the Past Discussions, doi:10.5194/cp-2015188.

Martinez, M., Pellenard, P., Deconinck, J.-F., Monna, F., Riquier, L., Boulila, S., Moiroud, M., Company, M., 2012. An orbital floating time scale of the Hauterivian/ Barremian GSSP from a magnetic susceptibility signal (Río Argos, Spain). Cretaceous Research 36, 106-115.

Mattioli, E. and Erba, E., 1999. Synthesis of calcareous nannofossil events in Tethyan Lower and Middle Jurassic successions. Rivista Italiana di Paleontologia e Stratigrafia 105, 343-376.

Mattioli, E. and Pittet, B., 2004. Spatial and temporal distribution of calcareous nannofossils along a proximal-distal transect in the Lower Jurassic of the Umbria-Marche Basin (central Italy). Palaeogeography, Palaeoclimatology, Palaeoecology 205, 295-316.

Mattioli, E., Pittet, B., Bucefalo Palliani, R., Röhl, H.-J., Schmid-Röhl, A., Morettini, E., 2004. Phytoplankton evidence for the timing and correlation of palaeoceanographical changes during the early Toarcian oceanic anoxic event (early Jurassic). Journal of the Geological Society, London 161, 685-693. 
Mattioli, E., Plancq, J., Boussaha, M., Duarte, L. V., Pittet, B., 2013. Calcareous nannofossil biostratigraphy: new data from the Lower Jurassic of the Lusitanian Basin. Comunicações Geológicas 100, 69-76.

McArthur, J.M., Janssen, N.M.M., Reboulet, S., Leng, M.J., Thirlwall, M.F., van de Schootbrugge, B., 2007. Palaeotemperatures, polar ice-volume, and isotope stratigraphy $\left(\mathrm{Mg} / \mathrm{Ca}, \delta^{18} \mathrm{O}, \delta{ }^{13} \mathrm{C},{ }^{87} \mathrm{Sr} /{ }^{86} \mathrm{Sr}\right)$ : The Early Cretaceous (Berriasian, Valanginian, Hauterivian). Palaeogeography, Palaeoclimatology, Palaeoecology 248, 391-430.

Meyers, S.R., 2012. Seeing red in cyclic stratigraphy: Spectral noise estimation for astrochronology. Paleoceanography 27, PA3228.

Meyers, S.R., 2014. astrochron: An R Package for Astrochronology. http://cran.r-project.org/package=astrochron.

Milhi, A., Ettaki, M., Chellai, E., Hadri, M., 2002. Les formations lithostratigraphiques jurassiques du Haut-Atlas central (Maroc): corrélations et reconstitutions paléogéographiques. Revue de Paléobiologie 21, 241-256.

Moiroud, M., Martinez, M., Deconinck, J.-F., Monna, F., Pellenard, P., Riquier, L., Company, M., 2012. High-resolution clay mineralogy as a proxy for orbital tuning: Example of the Hauterivian-Barremian transition in the Betic Cordillera (SE Spain). Sedimentary Geology 282, 336-346.

Mouterde, R., 1955. Le Lias de Peniche. Comunicações dos Serviços Geológicos de Portugal 36, 1-33.

Mutterlose, J. and Ruffell, A., 1999. Milankovitch-scale palaeoclimate changes in pale-dark bedding rhythms from the Early Cretaceous (Hauterivian and Barremian) of eastern England and northern Germany. Palaeogeography, Palaeoclimatology, Palaeoecology 154, 133-160.

Oehlert, A.M., Lamb-Wozniak, K.A., Devlin, Q.B., Mackenzie, G. J., Reijmer, J. J., Swart, P. K., 2012. The stable carbon isotopic composition of organic material in platform derived sediments: implications for reconstructing the global carbon cycle. Sedimentology 59, 319-335.

Page, K.N., 2003. The Lower Jurassic of Europe: its subdivision and correlation. Geological Survey of Denmark and Greenland Bulletin 1,23-59.

Pälike, H., Norris, R. D., Herrle, J. O., Wilson, P. A., Coxall, H. K., Lear, C. H., Shackleton, N. J., Tripati, A.K., Wade, B.S., 2006. The heartbeat of the Oligocene climate system. Science 314, 1894-1898.

Pellenard, P., Nomade, S., Martire, L., De Oliveira Ramalho, F., Monna, F., Guillou, H., 2013. The first 40Ar-39Ar date from Oxfordian ammonite-calibrated volcanic layers (bentonites) as a tie-point for the Late Jurassic. Geological Magazine 150, 1136-1142.

Perilli, N., 1999. Calibration of Early-Middle Toarcian nannofossil events in two expanded and continuous sections from the Basque-Cantabrian area (Northern Spain). Revista Española de Micropaleontología 31, 393-401.

Perilli, N., 2000. Calibration of early-middle Toarcian nannofossil events based on high-resolution ammonite biostratigraphy in two expanded sections from the Iberian Range (East Spain). Marine Micropaleontology 39, 293 308.
Perilli, N., Comas-Rengifo, M. J., Goy, A., 2004 . Calibration of the Pliensbachian-Toarcian calcareous nannofossil zone boundaries based on ammonites (Basque-Cantabrian area, Spain). Rivista Italiana di Paleontologia e Stratigrafia 110, 97-107.

Piqué, A., Tricart, P., Guiraud, R., Laville, E., Bouaziz, S., Amrhar, M., Ait Ouali, R., 2002. The Mesozoic-Cenozoic Atlas belt (North Africa): an overview. Geodinamica Acta 15, 185-208.

Pittet, B., Suan, G., Lenoir, F., Duarte, L. V., Mattioli, E., 2014. Carbon isotope evidence for sedimentary discontinuities in the lower Toarcian of the Lusitanian Basin (Portugal): Sea level change at the onset of the Oceanic Anoxic Event. Sedimentary Geology 303, 1-14.

Reggiani, L., Mattioli, E., Pittet, B., Duarte, L. V., Veiga de Oliveira, L.C., Comas-Rengifo, M.J., 2010. Pliensbachian (Early Jurassic) calcareous nannofossils from the Peniche section (Lusitanian Basin, Portugal): A clue for palaeoenvironmental reconstructions. Marine Micropaleontology 75, 1-16.

Rocha, R. B., Mattioli, E., Duarte, L. V., Pittet, B., Elmi, S., Mouterde, R., Cabral, M.C., Comas-Rengifo, M.J., Gómez, J.J., Goy, A., Hesselbo, S. P., Jenkyns, H. C., Littler, K., Mailliot, S., Veiga de Oliveira, L. C., Osete, M.L., Perilli, N., Pinto, S., Ruget, C., Suan, G., 2016. Base of the Toarcian Stage of the Lower Jurassic defined by the Global Boundary Stratotype Section and Point (GSSP) at the Peniche section (Portugal). Episodes 39, 460-481.

Ruebsam, W., Münzberger, P., Schwark, L., 2014. Chronology of the Early Toarcian environmental crisis in the Lorraine Sub-Basin (NE Paris Basin). Earth and Planetary Science Letters 404, 273-282.

Sabatino, N., Neri, R., Bellanca, A., Jenkyns, H.C., Baudin, F., Parisi, G., Masetti, D., 2009. Carbon-isotope records of the Early Jurassic (Toarcian) oceanic anoxic event from the Valdorbia (Umbria-Marche Apennines) and Monte Mangart (Julian Alps) sections: palaeoceanographic and stratigraphic implications. Sedimentology 56, 1307-1328.

Suan, G., Mattioli, E., Pittet, B., Lécuyer, C., SuchérasMarx, B., Duarte, L. V., Philippe, M., Reggiani, L., Martineau, F., 2010. Secular environmental precursors to Early Toarcian (Jurassic) extreme climate changes. Earth and Planetary Science Letters 290, 448-458.

Suan, G., Mattioli, E., Pittet, B., Mailliot, S., Lécuyer, C., 2008a. Evidence for major environmental perturbation prior to and during the Toarcian (Early Jurassic) oceanic anoxic event from the Lusitanian Basin, Portugal. Paleoceanography 23, PA1202.

Suan, G., Pittet, B., Bour, I., Mattioli, E., Duarte, L., Mailliot, S., 2008b. Duration of the Early Toarcian carbon isotope excursion deduced from spectral analysis: Consequence for its possible causes. Earth and Planetary Science Letters 267, 666-679.

Swart, P. K., 2008. Global synchronous changes in the carbon isotopic composition of carbonate sediments unrelated to changes in the global carbon cycle. Proceedings of the National Academy of Sciences 105, 13741-13745. 
Swart, P.K. and Eberli, G., 2005. The nature of the $\delta^{13} \mathrm{C}$ of periplatform sediments: implications for stratigraphy and the global carbon cycle. Sedimentary Geology 175, 115129.

Trecalli, A., Spangenberg, J., Adatte, T., Föllmi, K. B., Parente, M., 2012. Carbonate platform evidence of ocean acidification at the onset of the early Toarcian oceanic anoxic event. Earth and Planetary Science Letters 357358, 214-225.

Vennari, V.V., Lescano, M., Naipauer, M., Aguirre-Urreta, B., Concheyro, A., Schaltegger, U., Armstrong, R., Pimentel, M., Ramos, V. A., 2014. New constraints on the Jurassic-Cretaceous boundary in the High Andes using highprecision U-Pb data. Gondwana Research 26, 374-385.

Voigt, S., Aurag, A., Leis, F., Kaplan, U., 2007. Late Cenomanian to Middle Turonian high-resolution carbon isotope stratigraphy: New data from the Münsterland Cretaceous Basin, Germany. Earth and Planetary Science Letters 253, 196-210.

Wang, P., Tian, J., Lourens, L. J., 2010. Obscuring of long eccentricity cyclicity in Pleistocene oceanic carbon isotope records. Earth and Planetary Science Letters 290, 319-330.

Weedon, G.P. and Jenkyns, H.C., 1999. Cyclostratigraphy and the Early Jurassic timescale: Data from the Belemnite
Marls, Dorset, southern England. Geological Society of America Bulletin 111, 1823-1840.

Weedon, G.P., Jenkyns, H.C., Coe, A.L., Hesselbo, S.P., 1999. Astronomical calibration of the Jurassic time-scale from cyclostratigraphy in British mudrock formations. Philosophical Transactions of the Royal Society of London A: Mathematical, Physical and Engineering Sciences 357, 1787-1813.

Wilmsen, M., Blau, J., Meister, C., Mehdi, M., Neuweiler, F., 2002. Early Jurassic (Sinemurian to Toarcian) ammonites from the central High Atlas (Morocco) between Er-Rachidia and Rich. Revue de Paléobiologie 21, 149175.

Wilmsen, M., Neuweiler, F., 2008. Biosedimentology of the Early Jurassic post-extinction carbonate depositional system, central High Atlas rift basin, Morocco. Sedimentology $55,773-807$.

Zachos, J.C., Shackleton, N. J., Revenaugh, J. S., Pälike, H., Flower, B.P., 2001. Climate response to orbital forcing across the Oligocene-Miocene boundary. Science 292, 274-278.

Manuscript received: January 11, 2016

Revised version accepted: August 30, 2016. 